Historic, Archive Document

Do not assume content reflects current scientific knowledge, policies, or practices. 



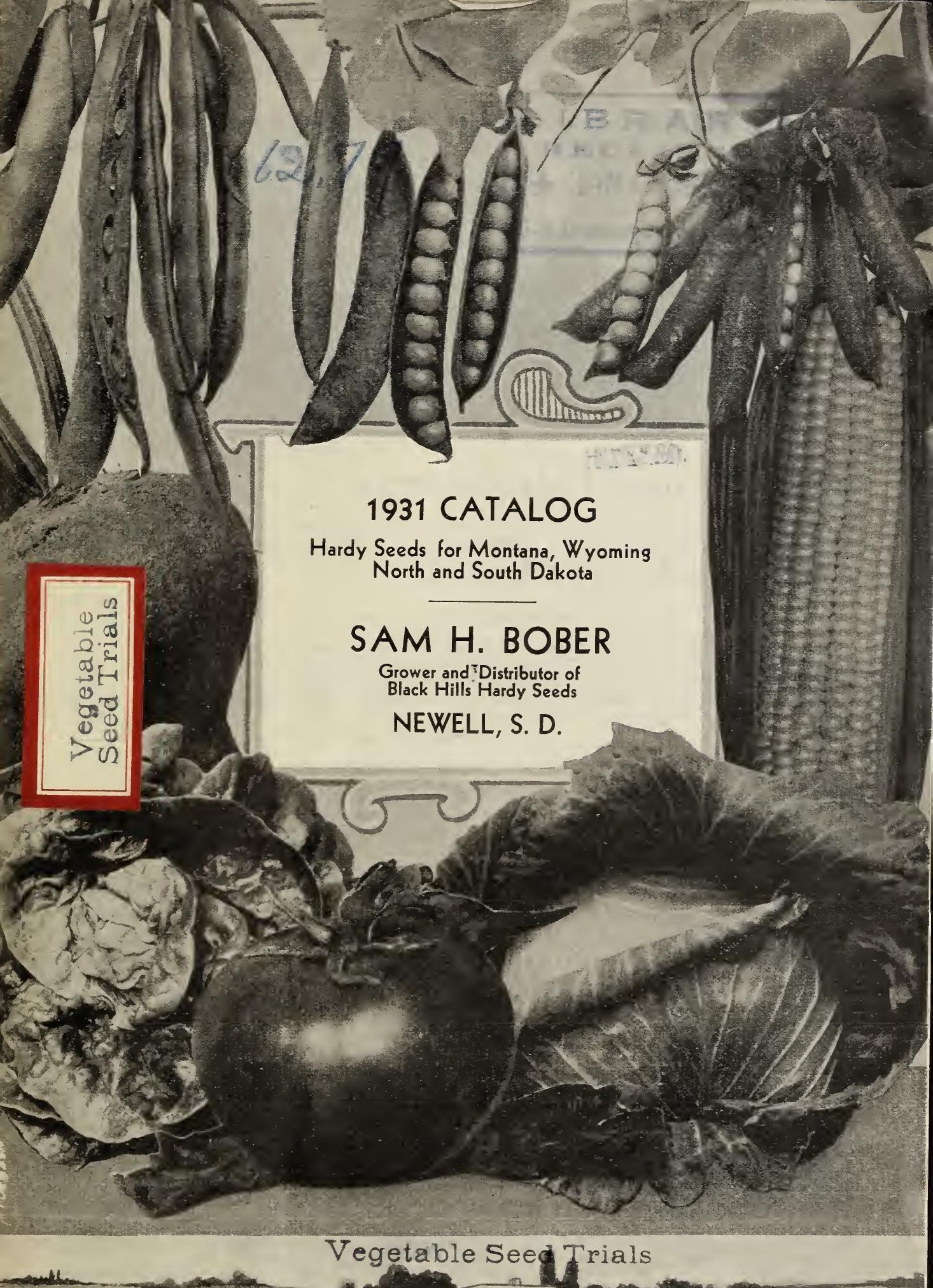




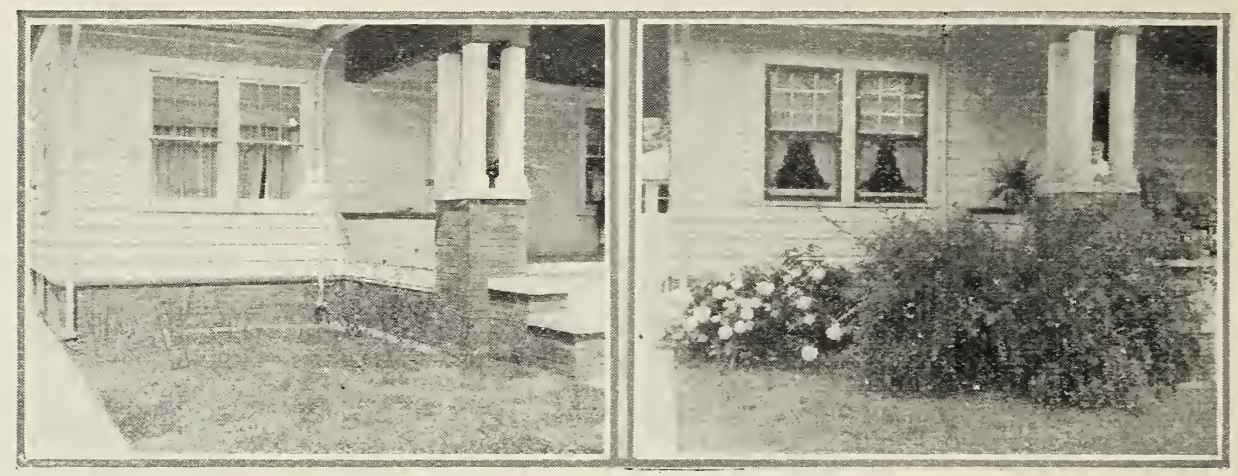

Before and After Planting a Few Bober Shrubs

\section{Friends and Customers:}

I WOULD love to come down to your home and pull the two chairs up to the old fireI place. I could take you by the hand and look you in the face and talk to you as a friend to a friend; but I have so many customers that this is impossible, so I am sending you my catalog, which is the only salesman that I have.

\section{Why Our List Is Small}

Our lifelong experience in this short season country has given us definite ideas of what constitutes a really good variety. We grow hundreds of varieties of garden and field crops for observation before we feel ready to pass them on to our customers. We wish to give permanent pleasure to you and therefore have listed only varieties of Early maturity, drought resistance and yielding ability which are worthy of a place in your fields.

\section{2,000 New Customers Last Year}

And we have retained all our old customers, too. Hundreds of letters were received telling us of the good luck they had and the large crops they have raised with our seed. Seed raised on our farms were awarded 35 blue ribbons at the State Crop Improvement Show, State Fair and County Fair. You will receive real value for your money and get much more pay for your work than is possible with longer season seed from eastern South Dakota or Iowa.

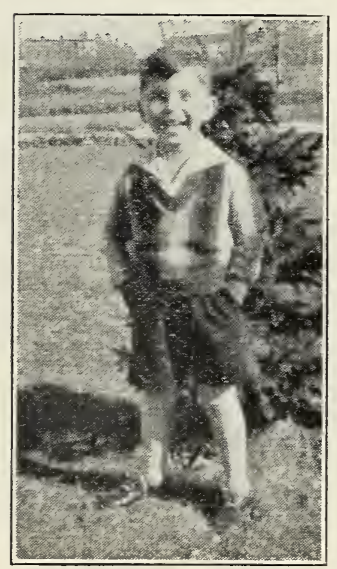

"JACKIE BOBER" The boss in the Bober family

\section{Stick to the Farms, Friends!}

It may seem tough going, but rarely so tough as in many of our large industrial centers at this time. Pluck, confidence and hard work will soon eliminate the uncertainty of the present business depression. Better times are ahead. Good luck to you in 1931.

\section{Terms of Sale and Shipment}

Payment: Cash in full with order. Money order, bank draft, check on good bank, or stamps accepted.

Delivery: We pay the postage or express on all Nursery Stock and Garden and Flower Seeds. All other items are F.O.B. Newell, unless otherwise stated.

Thousands of bushels of seed grain, seed corn, potatoes and flax go out to Wyoming, Montana and North Dakota by trucks at lower prices on account of large orders. Club your orders and ask for our special prices. It will save you money.

Newell is in Butte County, on the northern foothills of the Black Hills, about 30 miles from Montana line. We are on gravelled Highways 212 and 79 and not far from 85. Long distance telephone No. 52.

Use the Order Blank to be found in back of this catalog. 


\section{Plant a Big Garden This Spring $\underset{\substack{\text { For poesaure } \\ \text { for proat }}}{\text { prote }}$}

Raise your own vegetables and reduce your living expenses. Bober's Northern Grown Vegetable Seeds are the hardiest, earliest maturing and the best adapted for your garden.

EXTRA! We want early orders, and offer you a Magnificent Fern for orders reEX. ceived before March 1st. As a reward for promptness we will include FREF with each garden and flower seed order one luxuriant, beautiful FERN for each dollar's worth of seed. If your order amounts to $\$ 3$ we will send you free three beautiful ferns. Instead of Ferns $I$ can add 12 per cent more seed.

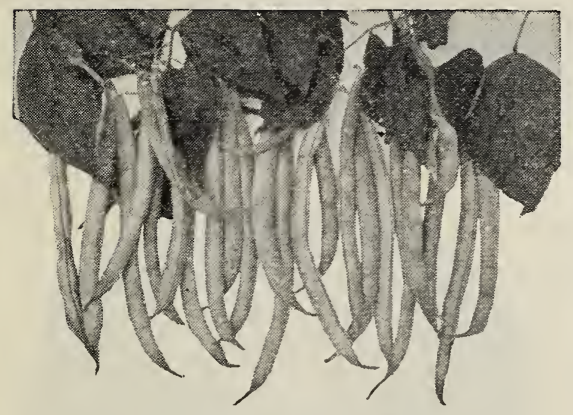

Improved Golden Wax

\section{Garden BEANS}

That Contribute Liberally to Your Table.

GREAT NORTHERN-The most delicious baking bean in the world. It takes the place of the little Navy bean, is a most wonderful producer, cooks in a very short time, is sweet and tender. Prices: $1 / 4$ 1b. 12c: $1 / 2$ 1b. 20c; 1b. 30c; 10 lbs. \$1.50; 100 lbs. $\$ 11.50$; prepaid.

PINTO Mexican Chili)-Excellent cooker, wonderful producer. Grows well here and will give an abundant supply. Prices: 1/2 1b. 10c; 1b. 20c; 5 lbs. 75e; 10 lbs. $\$ 1.30$.

BURPEE'S STRINGLESS GREEN POD-Widely grown green pod bead. Very early with meaty, stringless, brittle pods. Will ripen in 42 days. Prices: 1/4 1b. 15̄e; 1/2 1b. 23e; 1b. 35c; 5 lbs. \$1.35; prepaid.

RED KIDNEY-Pods about $5 \frac{1}{2}$ inches, produced in great numbers on dwarf bushes, 18 to 20 inches high. An early and large producer on our dry land farms. Pkt. 5e; $1 / 2$ lb. 20c; 1b. 30c; 5 lbs. \$1.00, prepaid.

IMPROVED GOLDEN WAX (My Pick)-This is the very finest selected strain of the Golden Wax bean, and has for years been our most popular variety. It is especially adapted to this section. A large seed company from Chicago likes these so well that they contracted quite an acreage to raise these seed beans for their trade. The pods are large, fleshy and stringless. The color is a bright golden. A very early sort and highly rust resistant. Plant plenty of these. They will pay. Prices: $1 / 4$ lb. 15c; 1/2 1b. 23c; 1b. 35c; 5 1bs. \$1.35; 10 1bs. \$2.50; and we pay the postage.

HENDERSON'S BUSH LIMA-Often called "baby lima" because of the small size seeds, which are white and flat. Very productive, and the earliest of the limas. Prices: Pkt. 10c; 1/4 1b. 15c; 1/2 1b. 25c; lb. $35 \mathrm{c} ; 5$ lbs. \$1.50.

BURPEE'S BUSH LIMA-Large seeded, delicious. Will mature in sixty days, making it good for our locality. Second earliest. Prices: Pkt. 10c; $1 / 4$ 1b. 15̄e; $1 / 2$ lb. 25e; 1b. 35e; 5 lbs. $\$ 1.50$

KENTUCKY WONDER-The best early pole wax bean for northern planting. Meaty and brittle. Pkt. 5c; 1/2 1b. 15e; lb. 30c; 5 lbs. \$1.30.

\section{Bober's Choice Garden PEAS}

LITTLE MARVEL-One of the newest and best of the wrinkled peas. It is sweet, productive and of high quality. $1 / 4$ lb. 15c; $1 / 2 \mathbf{2} 1 \mathbf{b}$. 22c; 1 b. $37 \mathrm{c} ; 5$ lbs. $\$ 1.30$; prepaid.

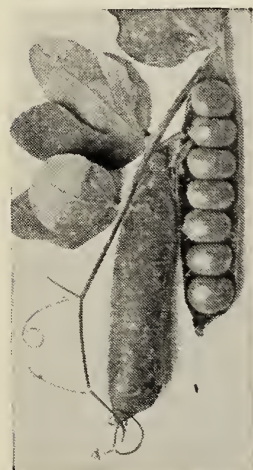

Improved Gradus Peas

BLISS EVERBEARING-If pods are picked as they mature the vines will continue to branch and bear all season. The best main crop variety. The peas are large, sweet and packed tight in the pod. Prices: 1/4 1b. 15c; 1/2 1b. 22c; lb. $37 \mathrm{c} ; 5$ lbs. $\$ 1.30$; prepaid.

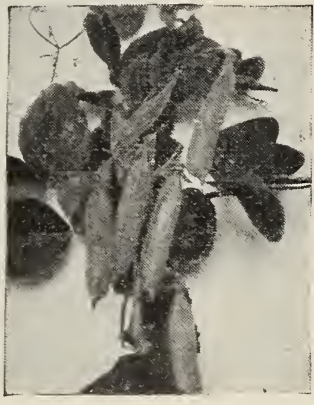

Everbearing Peas

ALASKA or EARLIEST OF ALL. (52 days to maturity.) A greater acreage of Alaska is planted by canners and gardeners than any other. Produces medium sized bright green peas of excellent quality. Matures its crop at one time. Prices: 1/4 11). 15c; 1/2 1b. 22c; 1b. 37c; 5 lbs. \$1.30; prepaid.

EXTRA EARLY GRADUS-A good early sort, produces large pods of wrinkled peas, and bears throughout the season. Prices: 1/4 1b. 15c; $1 / 2$ 1b. 22c; $1 b .37$ c; 5 lbs. $\$ 1.30$; prepaid.

PREMIUM GEY - A dwarf type of pea of delicious flavor. It is fine for the home garden. Prices: Pkt. 5e; $1 / 4$ 11. 15e; 1/2 1b. 22e; 1b. 37c.

LAXTONIAN-One of the finest and most profitable kinds to grow. A dwarf variety and is ready for gathering as early as the Gradus. Has a true marrow fat, delicious flavor. The pods are large,-if anything larger than the Gradus and better filled. Pods and vines are of rich healthy green. Prices: $1 / 4$ 1b. 15c; $1 / 2$ lb. 22e; $16.37 \mathrm{c} ; 5$ lbs. \$1.30; prepaid.

WORLD'S RECORD Or IMPROVED GRADUS. (My pick.) - One of the earliest of the wrinlkled, seeded, large podded varieties. The vines reach a height of 2 feet, produce most abundantly and bear throughout the season. These tender peas have a most delicious flavor and are the market gardener's favorite. Prices: $1 / 4$ 1b. 15c; $1 / 2$ 1b. 22c; 1b. 37c; 5 lbs. \$1.30;prepaid. 


\section{LETTUCE-The Best Salad Plant}

NEW YORK or WONDERFUL-A large variety of fine quality, more largely planted by commercial growers of head lettuce than any other sort. The heads are very solid, of finest quality, with outer leaves a rich dark green. It withstands heat and is one of the best heading sorts for the home garden. Prices: Pkt. $10 i ;$ oz. 20e; $1 / 416.25 c ; 1 / 216 . \$ 1.40 ; 1 b . \$ 2.50$.

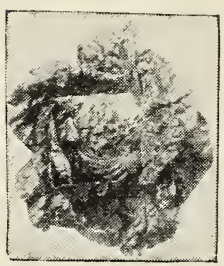

N. Y. Wonderful B LA C K SEEDED
SIMPSON-One of the most popular of all the early curled lettuce. Very tender and of delicate flavor. Prices: Pkt. 5e; oz. 15e; $1 / 41 b$. 40c; $1 / 2$ 1b. $70 \mathrm{c}$.

BIG BOSTON-Early, large, bright green heads. A very hardy and vigorous variety and one of the best known. Prices: Pkt. 5c; oz. 15e; $1 / 4$ lb. 55e; $1 / 2$ 1b. 95e; 1b. \$1.80.

\section{PARSLEY}

CHAMPION MOSS CURLED-Leaves finely curled, of a rich dark green. Use for garnishing and seasoning. Prices: Pkt. 5e; oz. 10c; $1 / 4 \mathrm{lb}$. 25e; $1 / 2$ 1b. $45 \mathrm{c} ; 5$ lbs. 80c.

\section{SPINACH}

NEWV ZEALAND-A thrifty variety that will stand hot weather. Continuous sprouting makes it desirable for home use. Prices: Pkt. 5e; oz. 10c; 1/4 1b. 35e; 1/2 1b. 55c; lb. \$1.00.

BLOOMSDALE-The earliest and hardiest variety. Crisp, crinkled broad leaved that keep well after cutting. Prices: Pkt. 5c; oz. 10c; $1 / 4$ lb. 20c; $1 / 2$ 1b. 30c; 1b. 50c.

\section{Bober's PUMPKINS Make Best Pies}

BOBER'S SWEET SUGAR Or NEW ENGLAND PIE.-This is the earliest and surest of the common sorts, and by far the sweetest. Especially valuable for the making of pies. A small, round Pumpkin, dark orange in color, with thick, dry, fine grained flesh. Pkt. 5c.

QUAKER PIE-Medium sized for home use, creamy white flesh. Keep well. An early and productive variety that is very hardy. Prices: Pkt. 5c; oz. 10c; $1 / 4$ lb. 35e; $1 / 2$ lb. 65e; 1b. \$1.20.

IING OF THE MAMMOTHS-The giant of pumpkins. Flesh a golden yellow, good quality and excellent for cooking. Prices; Pkt. 5c; oz. 15e; $1 / 41 b$. 50c; $1 / 2$ 1b. 90c; $1 b$. \$1.70.

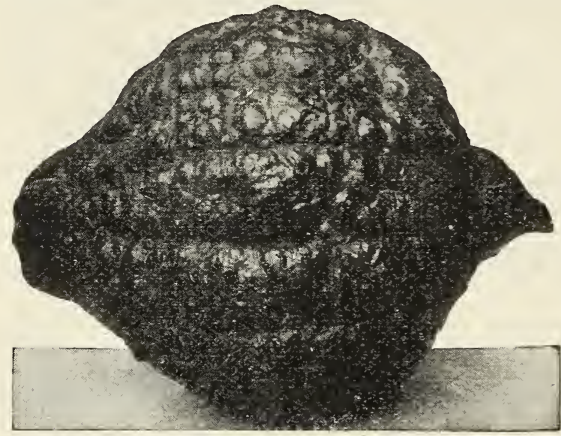

Hubbard Squash

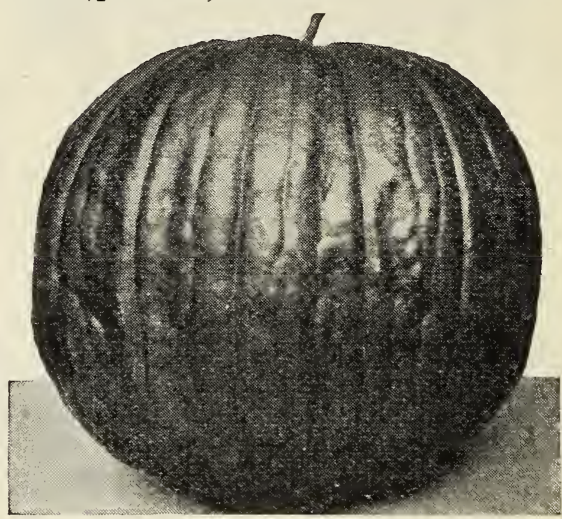

King of Mammoths

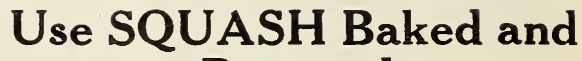
Buttered

BANANA SQUASH-Sweetest of all varieties and excellent for culinary use. Entirely free from fibre and stringiness. Prices: Pkt. 10c; oz. 20c.

TABLE QUEEN (My pick)-One of the finest little baking squashes grown. Also one of the earliest. However, it is not a baking squash alone. It will make splendid pumpkin pies. It is about the size of a quart cup, shaped like an acorn and will keep well for winter use. Some say it resists insect attacks, and I believe it will. Prices: Pkt. 5e; oz. 15e; $1 / 4$ lb. 60c; $1 b . \$ 1.90$.

IMPROVED HUBBARD-The standard winter squash, well known, highly productive variety. Flesh is bright yellow, fine grained and sweet. Prices: Pkt. 5c; oz. 15e; 1/4 1b. 40c; 1/2 1b. (i.je; ib. \$1.25.

\section{CUCUMBERS}

IMPROVED WHITE SPINE-One of the earliest of the cucumbers and a heavy producer. Prices: Pkt. 5e; oz. 12e; $1 / 4$ lb. 35e; $1 / 2$ lb. 60e; Ib. \$1.20.

I'T STAYS GREEN-A good pickling variety for continued picking. Recommended to all who put up their own pickles. Prices: Pkt. 5e; оz. 12e; $1 / 4$ 1b. 35e; $1 / 2$ 1b. 60c; 1b. \$1.20.

CHICAGO PICKLING-Old reliable variety for making small pickles. Especially good for marketing. Heavy producer. Prices: Pkt. 5e; (w. 12e; $1 / 4$ 1h. 35e; $1 / 2$ lb. 65e; 11 . \$1.20.

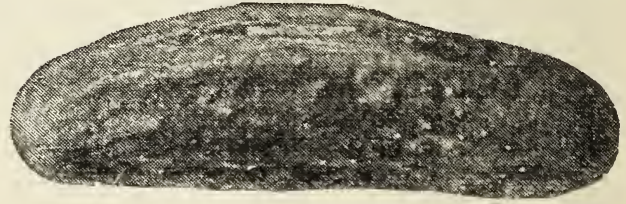

Stays Green Cucumber 


\section{Short Season WATERMELONS}

COLE'S EARLY-One of the earliest and best. Bright striped in two shades of green, with bright red flesh of delicious quality and thin rind. Prices: Pkt. 5e; oz. 10e; $1 / 4$ 1b. 30e; $1 / 2$ 1b. 50e; lb. 95 c.

PEERLESS or ICE CREAM-Very early, flesh is bright scarlet and is as sweet as honey. One of the best varieties of the north. Prices: Pkt. 5e; oz. 10e.

BOBER'S KLECKLEY SWEET (MY piek)This is a real quality melon. The flesh is fine grained tender and sweet. In fact, it is so tender that quite often it will pop open as soon as you stick a knife in it. If you want a better melon than this one you are hard to suit. Medium long

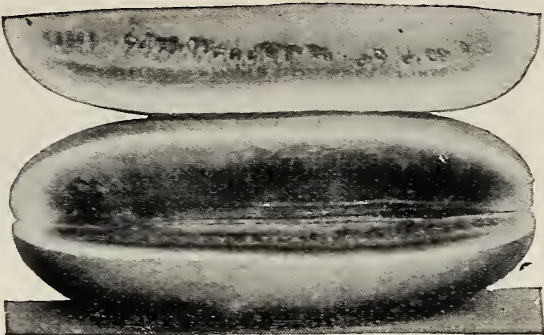

Bober's Kleckley Sweet or oblong in shape and skin dark green. A good big.melon weighing sometimes 40 pounds or even more. I received more letters from all sections including northern Montana praising this wonderful melon. You will be a booster for it, too. Prices: Pkt. 5c; oz. 10c; 1/4 1b. 30e; 1b. 85c.

WINTER WATERMELONS-Good in season with other melons and if stored in a cool, dry place will keep until Christmas. White rind, red flesh and black seeds. Prices: Pkt. 10c; oz. 15c; $1 / 4$ lb. 40c; $1 / 2$ lb. 65e; lb. $\$ 1.10$.

\section{MUSKMELON-Delicious and Appetizing}

EXTRA EARLY OSAGE-Earliest salmon fleshed variety. Oval dark green fruit. Ideal for the home garden. Prices: Pkt. 5e; 0z. 15c; 1/4 1b. 40c; 1/2 1b. 75c; $1 b . \$ 1.40$.

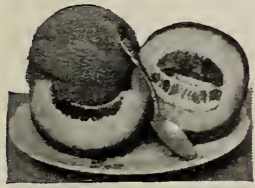

Muskmelon HONEY DEW-Preferred by most people. Six to eight inches in diameter with a hard white rind and green flesh. Command a high price on the market. Prices: Pkt. 5c; oz. 20c; $1 / 4$ 1b. $45 \mathrm{c}$; $1 / 2$ lb. 80c; 1 b. $\$ 1.50$.

WALWORTH'S GOLDEN CHAMPLAIN - The best of 34 varieties tried by the originator. High quality golden fruit that matures in 57 days. Two weeks earlier than other varieties. Prices: Pkt. 10c; oz. 20c; 1/4 1b. $50 \mathrm{c} ; 1 \mathrm{lb}$. $\$ 1.75$.

EMERALD GEM-Luscious salmon-pink flesh, thick and sweet. An excellent home garden melon. Pkt. 5e; oz. 15e: 1/4 lb. 45c: 1b. \$1.75.

HEARTS OF GOLD-Ripens immediately after Golden Champlain. Highest quality. Nearly solid meat, of beautiful salmon flesh. Pkt. 5e; oz. 15e; $1 / 4$ 1b. $45 c$; 1 b. $\$ 1.50$.

\section{DILL}

Familiar garden plant used in making pickles and for seasoning relishes. Prices: Pkt. 5e; oz. 10e; $1 / 4$ lb. 30e.

\section{RADISHES}

\section{Fresh, Crisp Radishes a Table Dainty}

Plant early using about one ounce of seed to 100 feet of row. Plant often so that you can always have them at their best.

FRENCH BREAKFAST-A half long, crisp, tender, quick growing radish, scarlet with white tip. Very early. Prices: Pkt.5e; oz. 10e; $1 / 4$ lb. 30c; $1 / 2$ 1b. 50e; 1 b. 95c.

ICICLE-The finest of the pure white varieties; very popular. Keep their unusually crisp and tender quality longer than red sorts. Prices: Pkt. 5c; oz. 10c; $1 / 4$ lb. 30c; $1 / 2$ lb. 50c; 1b. 9.5c.

BOBER'S SAXA-The earliest attractive, round, bright red radish. The flesh is pure white, crisp and has an agreeable snappy radish flavor. Grown in 20 days after planting. Pkt. 5c; oz. 15c; $1 / 41$ 1b. 40e; 1b. \$1.10.

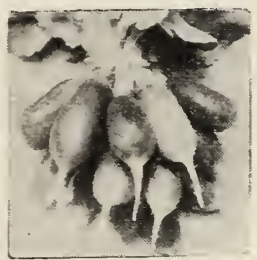

French Breakfast

\section{BEETS}

IMPROVED EGYPTIAN-Earliest and best bunching beet. Rounding flat root, bright red flesh, slightly zoned. Prices: Pkt. 5c; oz. 10c; 1/4 1b. 30c; 1/2 1b. 50c; 1b. 00c; prepaid.

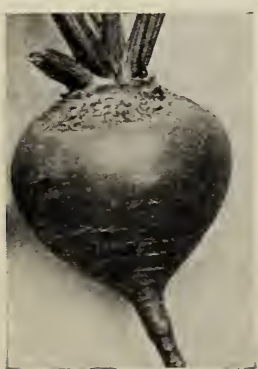

Egyptian Beet

DETROIT DARK RED-The beet that produces the main crop. Very tender and delicious, as well as attractive when canned. Prices: Pkt. 5c; oz. 10e; $1 / 4$ 1b. 30e; $1 / 2$ lb. 50c; lb. 90c; prepaid.

ECLIPSE-A very early variety with round, bright red roots. The flesh is crimson with pinkish white zones, sweet, crisp and tender. Prices: Pkt. 5c; oz. 10e; 1/4 lb. 30c; 1/2 lb. 50e; lb. 90e; prepaid.

\section{STOCK BEETS-Increase Milk and Egg Production}

GOLDEN TANKARD-A good cattle beet noted for its milk producing properties. Grows well above the ground and yields on light soils. Prices: Pkt. 5e; oz. 10c; $1 / 4$ lb. 30c; $1 / 2$ lb. 50e; 1b. 90c; prepaid.

MAMMOTH LONG RED-The heaviest cropping and largest of mangels, often yielding 40 tons per acre. Solid, straight, red roots. Prices: Pkt. 5e; oz. 10e; $1 / 4$ 1b. 30c; $1 / 2$ lb. 50e; 1b. 90c; prepaid.

SUGAR BEETS-Same variety used by beet raisers in Belle Fourche Valley for sugar production. This variety combines heavy yield with an extremely high sugar content. It is not only a source of sugar but an excellent stock feed and a heavy milk producer. Prices: Pkt. 5e; oz. 10e; $1 / 4$ lh. 30e; $1 \mathrm{~b}$. 90e; prepaid. 


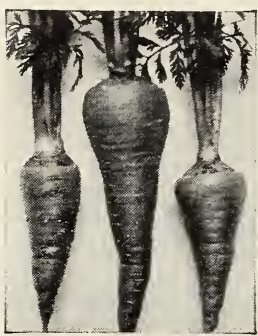

Danvers Carrot

\section{Use CARROTS for Health}

OX HEAR'T-Short, thick, orange fleshed roots. Sweet and fine grained; very early. Prices: Pkt. 5c; oz. 10c; $1 / 4$ 1b. 30c; $1 / 2$ 1b. 50c; 1b. 95e; prepaid. DANVERS HALF LONG-A large carrot of fine quality, deep orange in color, with close textured flesh and small core. Prices: Pkt. 5c; oz. 10c: $1 / 4$ lb. 30c; $1 / 2$ lb. 50c; 1 . 95c; prepaid.

CHA NTENAY-Excellent, medium early, half long, stump rooted variety. Roots are smooth with orange red flesh of finest quality. Prices: Pkt. 5c; oz. 10c; $1 / 4$ lb. 30c; $1 / 2$ lb. 50c; 1b. 95e; prepaid.

IMPROVED LONG ORANGE-An old standard sort, desirable for either field or garden use. Medium early, tremendous yielder; roots penetrate deeply so that plant gets moisture even in very dry weather, an important feature in the northwest. Roots about 12 inches long and 3 inches in diameter, flesh bright orange, smooth, sweet and fine-grained. A very good keeper. Prices: Pkt. 5c; oz. 10c; $1 / 4$ 1b. 30c; $1 / 2$ 1b. 50c; lb. 95e; prepaid.

\section{PARSNIPS for Winter and Early Spring}

IMPROVED GUERNSEY - Thick heavy roots with fine grained flesh of sweet quality. Prices: Pkt. 5e; oz. 10c; 1/4 1b. 25e; 1/2 1b. 45e; lb. 85e; prepaid.

LONG SMOOTH or HOLLOW CROWN-Large roots that are tender and sweet. A great producer and one of the very best varieties. Prices: Pkt. Je; oz. 10e; $1 / 4$ 1b. 25e; $1 / 2$ lb. 45e; lb. 85e; prepaid.

\section{RUTABAGA}

IMPROVED AMERICAN-Large globular roots with small tap root. Solid, tender, yellow flesh that is sweet and firm. Prices: Pkt. 5c; oz. 10c; $1 / 4$ 1b. 25e; $1 / 2$ lb. 40c; lb. 70c; prepaid.

\section{PEANUTS}

SPANISH-Earliest grown. Pods are small, but remarkably solid and well filled. Sow in drills 3 feet apart, placing the nuts 8 to 10 inches apart to allow for bushy habit of the plants. Pkt. 10c; 1/4 $1 b$. $15 \mathrm{c} ; 1 / 2$ 1b. 25e; $1 \mathrm{~b}$. 35c; postpaid. 5 lbs. $\$ 1.20$.

\section{TURNIPS}

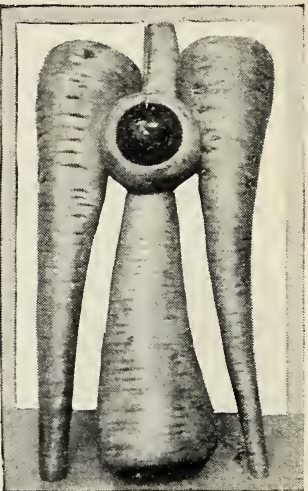

Long Smooth Parsuip

EXTRA EARLY PURPLE TOP-The earliest in cultivation. Medium sized roots, with purple tops. Prices: Pkt. 5e; oz. 10c; 1/4 1b. 25e; 1/2 lb. 45e; 1b. 80c; prepaid.

EXTRA EARLY WHITE MILAN-Creamy white roots of medium size, flat and uniform. Flesh is fine grained, tender and sweet. Priees: Pkt. 5c; oz. 10c; 1/4 1b. 25c; 1/2 1b. 45c; 1b. S0c; prepaid.

\section{SALSIFY or VEGETABLE OYSTER}

SANDWICH ISLAND-An improved type, double the size of the old variety. Long roots of excellent quality and delicate flavor. Makes real tasty soup. Prices: Pkt. 5e; oz. 25c; 1/4 lb. 90c; $1 / 2$ lb. $\$ 1.75$.

SUNFLOWER SEED-Mammoth big Russian, valuable poultry feed and for windbreak. Prices: Pkt. 5e; 1b. 30c; 10 lbs. $\$ 1.50$.

\section{CAULIFLOWER}

DANISH DRY WEATHER-Produces solid pure white. Especially adapted for growing in dry sections where nearly all other varieties fail to make good heads. Pkt. 15e; 1/4 oz. 50c; oz. \$2.00.

DANISH PERFECTION-This is the earliest cauliflower grown; heads small, round and uniform, quality excellent, keeping quality good. Can be placed on the market early to command the best price and is unexcelled for the home garden. A sure header, the inner leaves curl over, largely doing away with the need of tying up the heads. Prices: Pkt. 10c; oz. \$2.00.

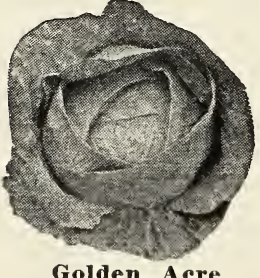

Golden Acre Cabbage

\section{Adapted CABBAGE Varieties}

DANISH BALIHEAD-One of the hardiest drought resistant cabbages; crisp, tender and sweet. Heads weigh very heavy. Prices: Pkt. 5ீ; oz. 25e; 1/4 1b. 90c; 1/2 1b. $\$ 1.75 ; 11$. $\$ 3.10$; postpaid.

BOBER'S GOLDEN ACRE-Earliest of all. A new early cabbage with a round hard head. Copenhagen type, but 10 days earlier. Because of its earliness and high quality it commands a higher price than other round head cabbage. Prices: Pkt. 10c; oz. 40c; $1 / 41 \mathrm{lb} . \$ 1.50 ; 1 / 2$ 1b. \$2.80; 1b. \$5.25.

COPENHAGEN MARKET-Early yielder of large, compact round heads. Heavy yielding and splendid quality make it most valuable. Prices: I'kt. 5e; oz. 25e; 1/4 1h. 90c; 1/2 1h. \$1.75; lb. \$3.10; postpaid.

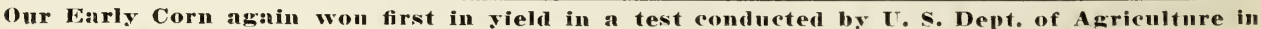
competition with 20 other varieties in two tests on dry land in Meade County. 


\section{SWEET CORN-Bober's Golden Sunrise a Money Maker}

GOLDEN SUNRISE-A new delicious golden sweet corn with the Golden Bantam flavor and two whole weeks earlier, it even beats the "Sunshine" by 3 days. It took 15 years to develop this sensational early corn. Remember its three big points: Large size, rich, buttery and delicious flavor, extremely early. You will have the first sweet corn for market and

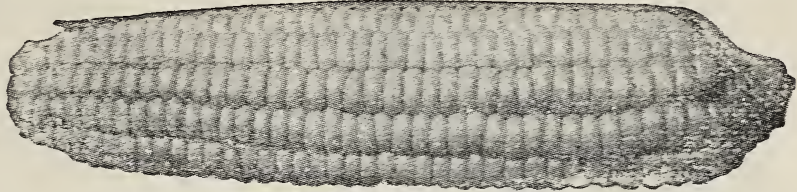

Golden Sunrise Corn

table in your neighborhood. It will make you good money. Sam recommends this variety. Prices: Pkt. 5c; 1/4 1b. 15c; 1/2 lb. 25e; 1 b. 37e; 5 lbs. \$1.10; 10 lbs. \$2.15; postpaid to your address.

GOLDEN BANTAN, BLACK HILLS SELECTION-A good quality sweet corn, rich, creamy yellow, sweet and tender. Prices: Pkt. 5c; $1 / 4$ 1b. 15e; 1/2 1b. 22c; 1b. 32c; $51 b s .90 c ; 101 b s . \$ 1.50$; postpaid.

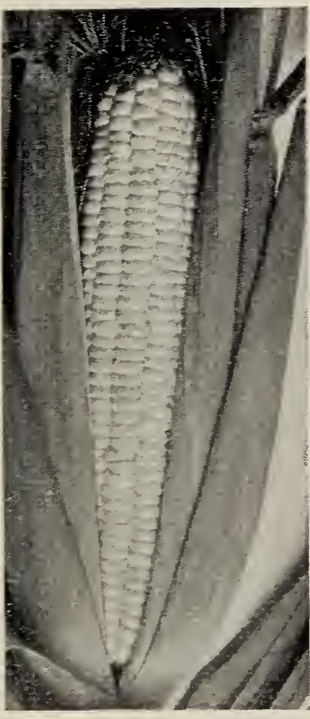

Bober's Golden Gem

STOWELL'S EVERGREEN-The standard main crop. Excels other late sorts in sweetness and productivity. Prices: Pkt. 5c; $1 / 4$ lb. 15c; $1 / 2$ 1b. 22c; 1b. 35̄e; 5 lbs. \$1.00.

SUNSHINE-Golden eared hybrid, originated by Prof. Yeager of North Dakota. It is 10 days earlier than Golden Bantam and much larger. A variety that should be in every garden. Prices: Pkt. 5e $1 / 4$ lb. 15c; $1 / 2$ lb. 25c; 1b. 37c; 5 lbs. \$1.10; 10 lbs. \$2.15; postpaid.

BOBER'S GOLDEX GEY SWEET CORN-Truly, present day accomplishments are little short of marvels! After having produced Golden Sunshine Corn, d remarkable early yellow sweet corn, Prof. A. F. Yeager, Horticulturist at the North Dakota Agricultural College Experiment Station, has bred Golden Gem Sweet corn, which is even 5 to 7 days earlier than that famous variety. We have secured our stock seed from Prof. Yeager. The ears are of good size averaging 7 to 8 inches in length, and are borne close to the ground on stalks about $3 \frac{1 / 2}{2}$ feet high. From one to three ears are produced on each stalk. Golden Gem is eight rowed; kernels are quite deep, broad, meaty, rich golden yellow, very tender and of the sweetest and most sugary flavor imaginable. The greatest feature however, is its extreme earliness! With Golden Gem, market gardeners may secure even better prices and home gardeners may have absolutely the very earliest yellow sweet corn. Crop very short. Only one pound to a customer this year. Prices: Pkt. 10c; 1/4 1b. 30c $1 / 2$ lb. 50c; lb. 85e; postpaid.

\section{SHORT SEASON POP CORN}

JAPANESE HULLESS-Of wonderful quality for popping; sells at a premium over all other sorts. Prices: Pkt. 5e; $1 / 41$ 1b. 15e; $1 / 2$ 1b. 20c; 1b. 35c.

WHITE RICE-Pearly white kernels resemble rice. Be sure to get the northern selection with which we can furnish you. Prices: Pkt. 5c; $1 / 4$ 1b. 10c; $1 / 2$ 1b. 20c; 1b. 32c.

\section{An ONION a Day Keeps the Doctor Away}

SOUTHPORT RED GLOBE-One of the finest types and a popular kind. This strain will ripen surely and keep well. A showy market onion. Prices: Pkt. 10e; oz. 30e; 1/4 1b. T5e; 1b. \$2.00.

DANVERS YELLOW GLOBE (MY Pick) Standard variety with orange yellow skin and white flesh of a crisp mild flavor. The earliest and longest keeping yellow globe onion. Prices: Pkt. 10e; oz. 30c; $1 / 4$ lb. S0c; lb. \$2.25. A winner in this section.

WELSH WINTER-The best perennial onion for your garden that will produce an abundance of the earliest green onions. Prices: Pkt. 10e: 1\%. 25e; 1/4 1b. S5e; $1 / 2$ 1b. $\$ 1.50$.

PRIZE TAIKER-Sweet Spanish type, large yellow onion. Grows to immense size. Prices: Pkt. 10e; oz. 25e; $1 / 4$ 1b. 70e; $1 / 2$ 1b. $\$ 1.25 ; 11$. $\$ 2.00$.

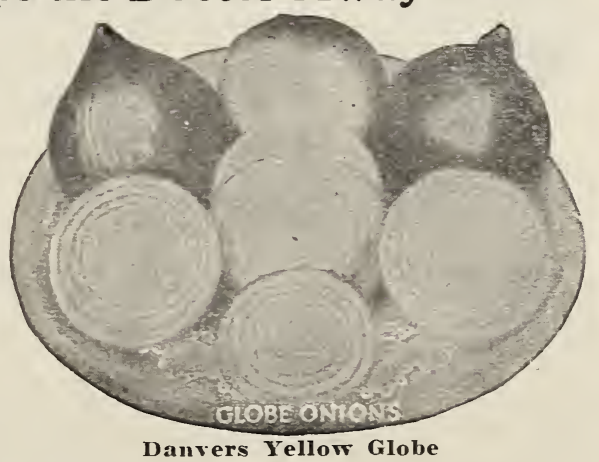

\section{POTATOES}

Changing seed is most important in growing potatoes. I offer best yielding Bliss Triumph seed potatoes grown from certified stock at \$2.50 per bushel; 5 busheis at \$2.10, not prepaid. Baver Dip Dust-Potato disinfectant, enough to disinfect 15 bushels seed potatoes in 2 minutes, $\$ 1.75$ per 1b. Takes 2 minutes instead of hours to disinfect and is more effective.

From North Dakota: We produced the largest watermelons in the county from your Bober's líeckley sweets. Your Danver's Yellow Globe Onion paid big. 


\section{SHORT SEASON TOMATOES}

Richest in vitamins. Use tomatoes in soups, salads, and sliced. One of our customers sold 15 tons tonatoes to the stores, raised from John Baer and Earliana seed we sold him.

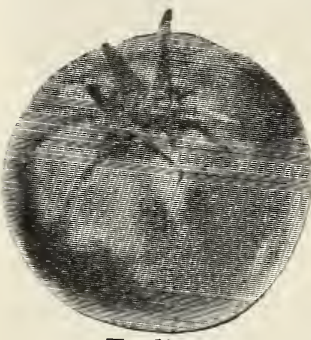

Earliana

EARLIANA-The earliest of all tomatoes. Fruit round, smooth, red flesh and very meaty. Ripens over long season. Medium size tomatoes in clusters, plants very productive. Prices: Pkt. 5e; oz. 30c; $1 / 4$ lb. \$1.10.

RED HEAD-A deep blood red tomato that does not crack open easily and it is practically resistant to blight. Prices: Pkt. 10c; oz, 40c; $1 / 4$ lb. \$1.35.

BONNY BEST-Fruits ripen evenly, and are of superior solidity and interior color than many varieties. Smooth, round Prices: Pkt. 10c; oz. 35e; $1 / 4$ 1b. $\$ 1.20$.

JOHN BAER-An early bright red tomato, ripens evenly up to the stem. Does not scald, blight or crack. A fine tomato for this section. Pkt. 10c; $1 / 2$ oz. 20c; oz. 35c; $1 / 4$ lb. \$1.20.

YELLOW PLUM-Resembles a plum in size and shape. Of good flavor and especially desirable for preserving. Prices: Pkt. 10c; oz. 45c.

YELLOW PEAR-Small pear shaped fruit of delicate flesh and fia.

vor. Excellent for pickling and preserving. Prices: Pkt. 10c; oz. 40c.

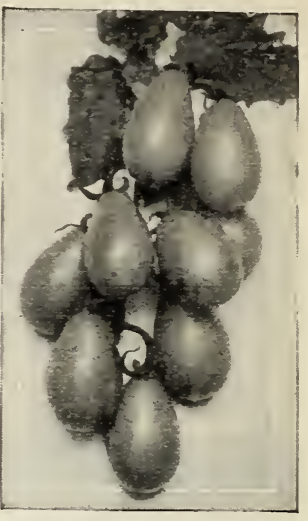

Yellow Pear

GROUND CHERRY or HUSK TOMATO-Unequalled for canning, preserving, or making pies. Bushy vines yield immense crops. Prices: Pkt. 10c; oz. 50c.

\section{VEGETABLE PLANTS}

Plants are perishable, especially tomato plants which frequently dry out in inland post offices. We cannot guarantee safe delivery of these plants except to town people who call for them promptly.

Our vegetable plants are well grown and very sturdy and will give you the best possible results. Many people prefer to buy the started plants of those things that must be started in hotbeds than to bother with the seeds themselves.

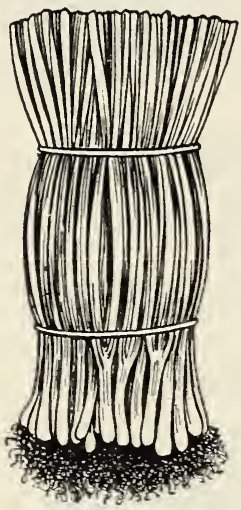

Bermuda Onion Plants

\section{Vegetable} Cabo-Golden Acre, extra early...............40

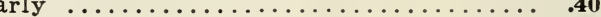

Celery-Self blanching, good variety ............45

Egg Plant-Large, purple black ................65

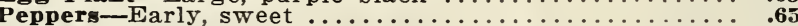

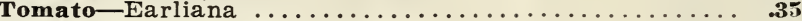

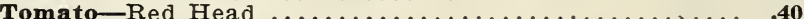

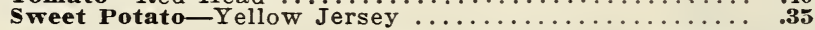

\section{BERMUDA ONION PLANTS}

Can be planted April 1st to August 1st. Keep these in a dry place until planted. It does not hurt tops of these onion bulbs to dry out The mildest and sweetest of all onions. Large yields of delicious Bermudas, that will bring you good returns for your investment. Bermudas are in great demand and you should get in on the ground floor to get your share of the profits. Buy our strain and insure yourself for the best chance for success with Bermudas. Prices: 200, 50c; 500, $\$ 1.05 ; 1,000, \$ 1.75$. Crate of 6,000 plants, $\$ 6.75$, prepaid.

\section{ONION SETS}

For large onions in one season plant our onion sets, which have been raised from the purest strains of seed. One bushel is 32 pounds.

\section{PRICES}

Variety

Pt. Qt. 1/2 Pk, Pk. 1/. Bu, Bu.

White Bottom ....20e 32c 90e $\$ 1.40$ \$2.50 $\$ 4.75$

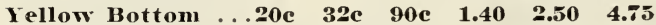

Red Botton .....20e 32c 90e 1.40 2.50 4.75

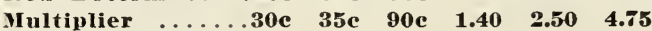

Potato Onions

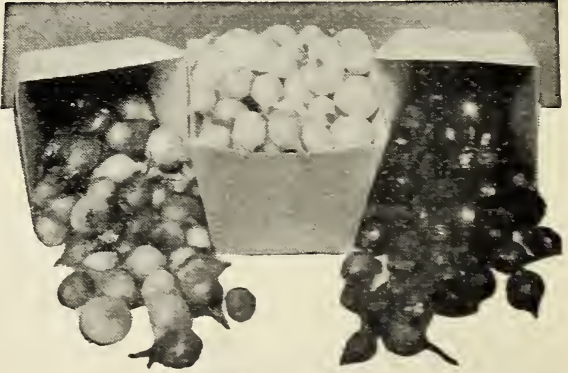

Onion Sets

GARLIC-Whole, sound, white for seed or pickling. Ib. 40c: 5 lbs. \$1.60; postpaid. 


\section{WHEAT}

The farm board advises less wheat acreage. However, what you do plant you better sow a variety that produces the most under our conditions.

NEW CERES HARD SPRING WVHEAT-Ceres is the most important wheat introduction since the Marquis first came in. It is very rust resistant, high yielding under nearly all conditions, does not shell out badly, has a very excellent milling and baking test, and is slightly earlier than Marquis. CERES is a bearded wheat, being a cross between Kota and Marquis. It is a product of the breeding work of the North Dakota Experiment Station. It beats Hope wheat and we sell it at prices you can afford: $\$ 1.50$ bushel; 10 bushels at \$1.35. Free bags.

KUBANKA-The most rust resisting, drouth resisting and highest yielding selection of Durum or Macaroni wheat. Grain is of fine quality amber durum, and is very extensively planted. I obtained my seed direct from the U. S. Department of Agriculture. Price per bu. $\$ 1.10$.

MARQUIS-The high quality hard spring wheat. Our strain is pure and of the best selection. Price per bu.

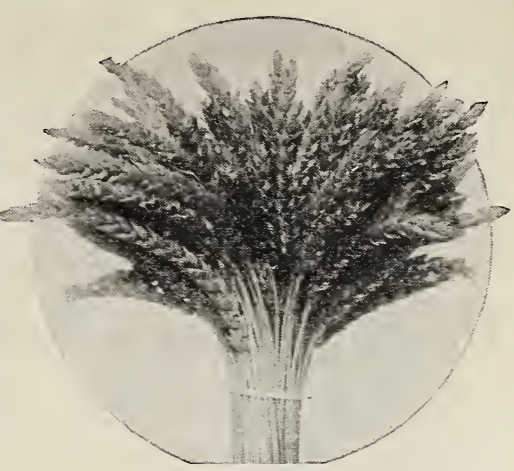

Kubanka Wheat

1.10 .

RUBY WHEAT-About a week earlier than Marquis. It is a bald wheat of fine milling quality, with nice hard red berry, and straw of medium height. The great value of Ruby lies

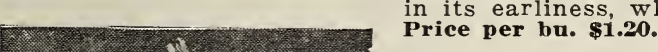

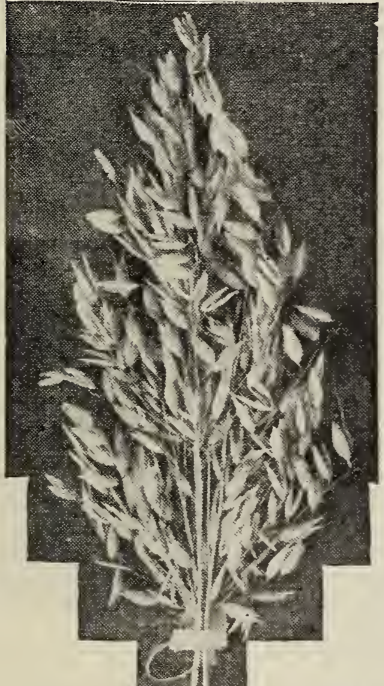
which enables it to escape drought and rust. The Best FLAX

First Prize at State Crop Improvement Show

I can now supply you the highest yielding, the most rust and wilt resistant Registered Certified Bison Flax seed, the out standing variety that all northwest agricultural colleges and U. S. Dept. of Agriculture recommend. There will be ordinary common or South American flax seed which some will try to sell you for Bison. Be on your guard and demand the registered genuine highest yielding Bison flax. We can supply it for early orders at $\$ 3.50$ per bushel; 5 bushels at $\$ 3.35 ; 10$ bushels at $\$ 3.15$ $I$ also have Buda and No. 114 flax seed not certified at $\$ 3.00$ per bushel; 5 bushels at $\$ 2.85 ; 10$ bushels at $\mathbf{\$ 2 . 6 0}$. Special prices for large orders. Flax will always be the best cash crop in this section.

\section{BARLEY}

YEW VELVET BARLEY - Introduced by Minnesota Experiment Station. Grown by us on dry land for 2 years. As its name indicates it has beards as smooth as velvet. No scratch or irritation to harvesters or to stock. It does not yield as good as Trebi barley. I am pricing it low enough to give every farm a chance to try it out. Price: 1 bu. $\$ 1.50 ; 2$ bu. $\$ 2.75 ; 10$ bu. $\$ 11.25$.

PEDIGREED TREBI BARLEY - This heaviest yielding, largest grain variety is adapted to better land or low land along river or creek bottom. It will produce more pounds of grain per acre than any other crop. Ty a few acres and be convinced. Price: $\$ 1.45$ bu; 2 bu. $\$ 2.65 ; 10$ bu. $\$ 12.00$. This Trebi barley made a record yield of 100 bushels per acre in Butte County.

\section{NEW IMPROVED}

BLACK HILLS WHITE HULLESS AND BEARDLESS BARLEY

Has neither beards nor hulls, extremely early, making it very valuable for hog feed and poultry. Yields immense crops that thresh out from the hull just as wheat does. Better and richer for feeding purposes than any other barley. Normally producing two to three times the yield of the best wheat. Prices: $\$ 3.00$ per 100 lbs.

\section{RAPE}

DWARF ESSEX-One of the very best pasturing plants for cattle, hogs and sheep. Thrives best in low moist soil or creek bottom land, and will grow out as fast as it is eaten off. Price: 5 lbs. 95c; 10 Ibs. \$1.30; 25 Ibs. $\$ 3.25 ; 100$ lbs. $\$ 11.00$.

Gopher No. 674 Oats

\section{OATS}

BURT No. 293 OATS-A new pedigreed variety outstanding in yield in co-operative tests and in experiment station trials. Ripens even earlier than the 60 day variety. This new oat should prove popular in all parts of North and South Dakota, Wyoming and Montana. It yielded 70 bushels per acre on heavy upland soil on breaking. If you want new, pure, big yielding early oats, send in your order to Sam at once. Price: 90c per bushel; 3 bu. \$2.50; 10 bu. $\$ 7.50$.

\section{RECORD YIELD IX OATS}

I can also supply you the new Gopher Oats, No. 674. This is a white seeded early maturing oat, having stiff straw and open panicles, is a big yielder and of good weight. These oats have a trace of about 1 to 2 per cent barley. Jeremiason \& Sons who live 14 miles west of here had a record vield of 131 bushels per acre of these Gopher Oats on 6 acres dry land. I have a limited supply of these good oats. So rush your order. Price: 90c per bu; 10 bu. \$8.20.

SIXTY DAY Or KHERSON OATS-The standard early oats for the northwest. Pure seed, recleaned and best on the market. Price: s0c wer bushel; 10 bu. \$7.00. Swedish Select Oats for your creek bottom or irrigated land, special heavy yielding selection. Price; bu. o0c: 10 bu. $\$ 7.20$. 


\section{NEW DWARF WHITE SWEET CLOVER}

A wonderful feed and seed producer. Does not grow rank and coarse like the common white sweet clover. Produces most excellent pasture for dairy and beef cattle, sheep and horses, or will make a fine quality and quantity of hay from $10 \mathrm{lbs}$. of seed per acre. For seed production it has no equal. It yielded $101 / 2$ bushels of seed on dry upland per acre for me. It made as high as 16 bushels per acre of clean seed. It's a sure producer. It is unusually hardy, withstands dry summers and cold winters. The crop starts growth early in the spring, produces an abundance of pasture. You need it on your farm. Price: $\$ 10.50$ per 100 lbs. Bags free.

\section{Prof. Hansen's Proso or Hershey}

Awarded first prize at State Crop Show last four years. Also known as Hershey, and hog millet. One of the greatest dry land grain crops.

In the north it will become a staple grain crop, because it will ripen in sixty days after sowing in an eight inch rainfall country, yielding three hundred fold. This means one pound sown in late June or July will bring four or five bushels of good grain that will weigh 60 to 64 pounds to the bushel. It is fine for poultry feed and will fatten hogs and cattle for the market.

Hansen Proso Prices: 10 lbs. \$1.00; 25 lbs. \$1.50; 50 lbs. \$2.50; 100 1bs. \$4.50.

\section{MILLET}

DAKOTA KURSK MILLET-Pedigreed selection No. 79.-Experiments conducted at the Experiment Stations in South Dakota have demonstrated beyond dispute the value of this variety. As a hay and seed producer it is without equal and in dry seasons it seems it will outyield any other variety. Prices: 50 lbs. \$2.50; 100 lbs. \$4.50.

\section{SOY BEANS}

ILLINI-This bean was bred up by the College of Agriculture, Urbana. We have been using this bean three years, and it has made rapid progress. This bean is especially popular with the men who have combines. The reasons are as follows: (1) It stands up the best of all varieties. (2) The bean matures earlier than Manchu, and is usually threshed before the fall rains. (3) They do not shatter. (4) The bean stands much more wet weather after maturing without damage, than does the Manchu. (5) The yield is the greatest, as high as 37 bushels per acre. The Illini I have yielded 33 bushels per acre this year. They test 98 per cent, and contain less than 2 per cent cracks. Excellent for hay and silage. 10 lbs. \$1.25; 50 lbs. \$4.00; 100 lbs. \$7.00.

\section{SWEET CLOVER}

White or yellow sweet clover, best grade cleaned, scarified and sacked $\$ 10.00$ per 100 lbs. Subject to market change after Mar. 1st.

\section{SUDAN GRASS}

Plant for hay and summer pasture. Sow May 15th to June 10th. Adapted to any soil and will yield a crop of heavy, leafy, finestemmed hay crop that is easily and quickly cured. Easy to handle. Bind as corn fodder and stack for winter feeding, if you like. Prices: 15 lbs. $\$ 1.95 ; 50$ lbs. \$6.00; 100 lbs. \$11.

\section{BROME GRASS}

This makes a good crop for pasture especially, and will do for hay although it is not of the best quality for the latter. Unequalled for hardiness and sturdiness. Will grow on most any soil and do well. Sow 7 to 15 pounds per acre for best results. Prices: lb. 35c; 15 lbs. \$4.50; 50 lbs. \$12.00; 100 lbs. \$23.00.

\section{EARLY BLACK AMBER CANE}

\section{The Big Feed Producer}

Cane will cut the cost of feeding cattle and sheep both as dry fodder and for silage. This is earlier than the southern types and not so tall. It grows right along through the severest and most prolonged drought. Prices: 1b. $25 c ; 10$ lbs. $\$ 1.00 ; 50$ lbs. $\$ 3.50 ; 100$ lbs. $\$ 6.75$.

\section{ALFALFA}

\section{Buy Less-Raise More Protein}

These simple words express the soundest advice that can be given today to farmers and stockmen. Best grade Grimm alfalfa \$27 per 100 lbs. Cossack, \$30.00. Dakota No. 12, \$23.50. Second grade alfalfa, 98.5 per cent purity, \$18 per 100 lbs. 97 per cent purity, \$15 per 100 lbs.

\section{FOR SEED PRO- DUCTION}

St a t e Registered blue tag Grimm at $\$ 34$ per 100 lbs. Same $\mathrm{grade}$ Registered Cossack, \$37 per 100 lbs. Smaller lots 1c 1b. higher. Free bags. 


\section{Flower Seeds for Northwest Farms and Homes}

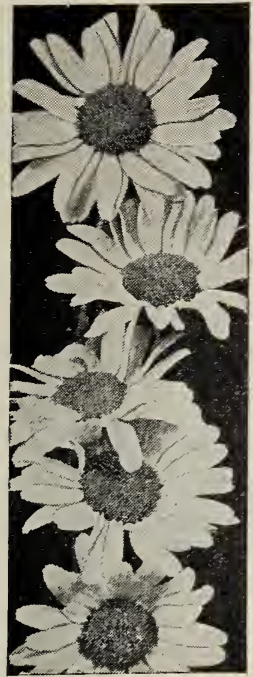

Shasta Daisies

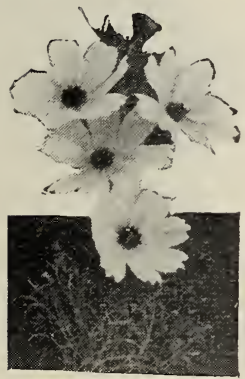

Cosmos

\section{Northern Grown}

ASTERS-Purity White, Crimson, Lavender or Purple. Pkt. 10c; $1 / 4$ oz. 40c.

ALYSSUM-Sweet Alyssum White. Pkt. 5e; $1 / 2$ oz. 15c.

LILAC QUEEN-Deep lavender. Pkt. 5e; 1/2 oz. 25c.

BACHELOR'S BUTTON-Corn flower-double blue. Pkt. 10c; 1/4 oz. 20c. Double mixed. Pkt. 5c; $1 / 4$ oz. 15c.

BALLOON VINE-Sometimes called "Love in a Puff." Pkt. 5c: oz. 25c.

BALSAM-Lady Slipper-double Camelia flowered. Pkt. 5c; $1 / 4$ oz. 20c.

BEANS-Scarlet Runner Pkt, 5e; 1/4 lb, 20c.

BEE BALM-Spider Plant. Pkt. Je.

CALENDULA-Pot Marigold. Orange King Pkt. 5c; $1 / 4$ oz. 15c.

CALLIOPSIS-Tickseed. Pkt. 5c; $1 / 2$ oz. 20c.

CANARY BIRD FLOWER-Pkt. 5c: oz. 30c.

CANDYTUFT-Giant flowering mixed. Pkt. 5c; $1 / 2$ oz. 20c.

CANTERBURY BELLS-Single mixed. Pkt. 5e; $1 / 4$ oz. 25c.

CARNATION-Dwarf Margaret. Pkt. 10c; $1 / 4$ oz. 40c.

CARNATION-Chabaud mixed. Pkt. 15e; 1/4 oz. 65c.

CATCHFLY-Pkt. 5e; 1/4 oz. 25c.

CENTA UREA IMPERIALIS-Giant Swiss Sultan. Pkt. 10e; $1 / 4$ oz. 25c.

CHINESE LANTERN PLANT-Pkt. 10c; $1 / 40 z$ 40c.

CHIRYSANTHEMUM-French Marguerite. Pkt. бс; 1/2 оZ, 20c.

CLARKIA-Double mixed. Pkt. 10e: $1 / 4$ oz. 20c.

CATHEDRAL BELLS-Annual Climbers, beau -

tiful. Pkt. 10c; $1 / 4$ oz. 20c.

Cosyos-Single mixed. Pkt. 5e; 1/4 oz. 20c.

COSMOS-Double mixed. Pkt. 10c; $1 / 4$ oz. 60c

WILD CUCUMBER-Pkt. 5c; oz. 15e.

CYPRESS VINE-Pkt. Te; 1/2 oz. 25e.

SUMMER CYPRESS-Burning Bush. Pkt. 5c DAISIES-Shasta. Pkt. 10c; $1 / 4$ oz. 90c.

DIANTHUS-Chinese Pink. Pkt. 5c; 1/1 oz, 20c. FORGET-ME-NOT-Pkt. 10e; $1 / 4$ oz. 30c.

FoUr o'CLOCK-Marvel of Peru. Pkt. Јc; oz.

GERA NIUM-Pkt. 10c.

HELIANTHUS-Chrysanthemum flowered. Pkt. 5с; оz. 25c.

HELIO'TROPE-Pkt. 5c.

ICE PLAN'T-Pkt. 5e.

LARKSPUR-Delphinium. Pkt. 10e; 1/4 oz. 30c. MARIGOLD-French mixed. Pkt. 5e; $1 / 4$ oz. 20c. MIGNONETTE-Machet. Pkt. 5c.

HOLLYHOCIK-Double mixed Pkt, 10c; 1/4 oz, 35c.

HOLLYHOCK-Single mixed. Pkt. 5c; $1 / 4$ oz. 20c.

HOLLYHOCK-Annual finest mixed. Pkt. 10c; $1 / 4 \mathrm{oz} .30 \mathrm{c}$

FINEST MIXED MORNING GLORY-Pkt. 5e; oz. 15c.

JAPANESE MORNING GLORY-Pkt. 5e; oz. 20e.

NASTURTIUM-Dwarf mixed. Pkt. Jc; oz. 15c.

NASTURTIUM-Tall mixed. Pkt. 5c; oz. 15c.

PANSIES-Premium mixture. Pkt. 5e; 1/4 oz. 75e.

PANSIES-Bronze or Yellow Mastodon. Pkt. 15e. PETUNIAs - Rosy Morn. Pkt. 10c.

PETUNIAS-Hybrid mixture. Pkt. 10c.

Portulaca-Rose Moss double mixed, 10c: single mixed, 5e pkt.

PRIMRose-Japanese. Pkt. 10c.

PHLOX-Annual. Pkt. 10e; 1/4 oz. 40c.

POPPIES - Carnation double mixed. Pkt. 5e.

POPPIES - Flanders-scarlet red. Pkt. 10c.

POPPIES-Shirley-Mixed colors. Pkt. 10c.

RICINUS-Castor Bean. Pkt. 10e.

SCABIOSA-Mourning Bride. Pkt. 5e; 1/4 oz. 20c.

SNOW ON THE MOUNTAIN-Pkt. 10c; $1 / 4$ oz. 30c.

STOCKS-Dwarf, 10 weeks. Pkt. 10c; 1/4 oz. 30c.

SWEET PEAS-Mixed. Pkt. 5e; $1 / 4$ oz. 35e; $1 / 21$ 1b. 60c.

SWEET PEAS-Giant Spencer Mixed. Pkt. 10e; $1 / 4$ ib.

50c.

SWEET ROCKET-Hesperis, Pkt, 10e; o\%, 30c.

SWEET WILLIAM-Pkt. 10c; $1 / 4$ oz. 30c.

VERBENA HYBRIDA-Pkt. 10e; $1 / 4$ oz. 35c.

ZINNIA - Dahlia Flowering. Pkt, 10e; 1/407 506.

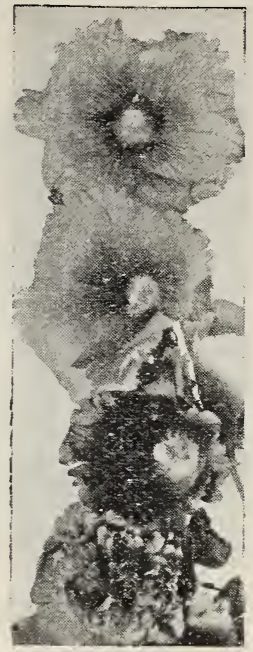

Hollyhocks

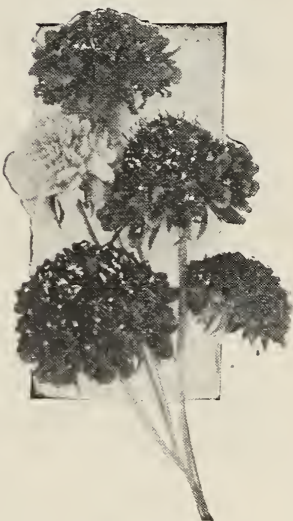

Scabiosa

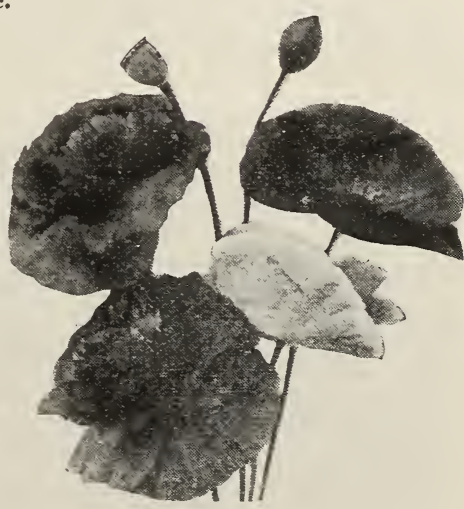

Poppies 



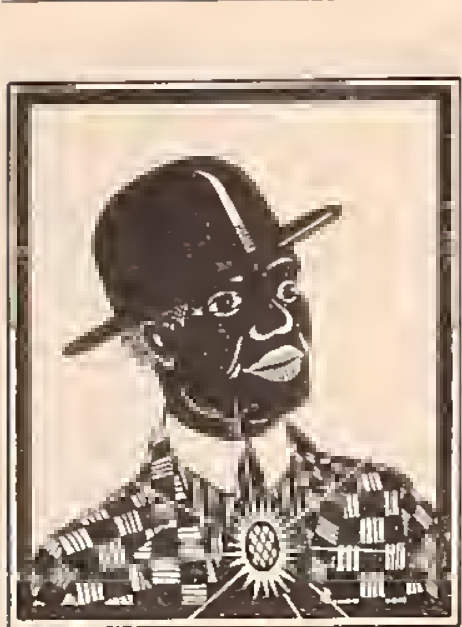

RASTUS SPORTS A "SPARKLER"

Payne's White Dent-the Record Breaker My Payne's White Dent made a record of 91 bushels of corn to the
acre on 10 acres dry land for Jas. McNeil, St. Onge, S. D., in a 10 -acre

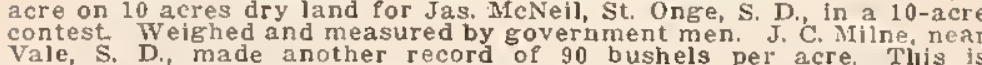

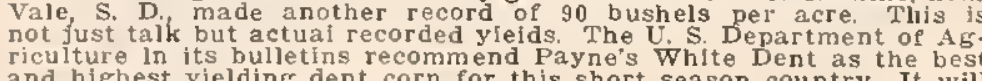
and higbest yielding dent corn for this short season country. It will produce the most ripe corn and the most meat per acre whether
sheepor hogs or cattle are used to larvest it. Try at least a bushel
against any corn. It will be an exe opener.

Bober's Minnesota 13 Yellow Dent

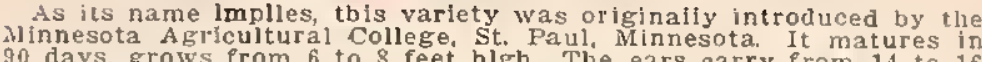
90 days, grows from 6 to 8 feet hlgh. The ears carry from 14 to 1

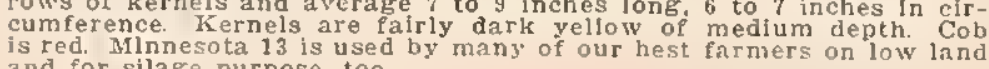

Bober's Gehu Seventy-Day Yellow Corn

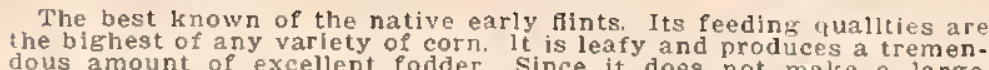
dous amount of excellent fodder. Since it does not make a large.
heavy stalk every part of the plant ls utilized in peeding.
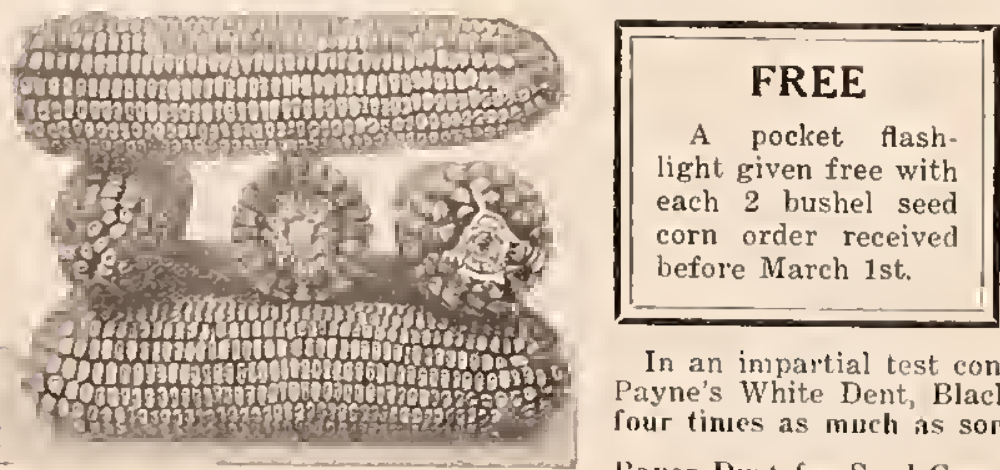

,

In an inpartial test conducted by the State Collect on high and dry gumbo soil, Sam Bober's Falconer corn, Payne's White Dent, Black Hills Special yellow dent and Gehu flint made the best yields, yielding as high as four times as much as some of the other varieties in the same test.

Huck Hills sperial liaver Dust for Seed Corn- $\$ 1.75$ per pouml. Will treat seed corn for 35 acres. Good clieap insurance against unfavorable weather. 等
S A M B O B E R'S CORN has YIELDING ABILITY and DROUGHT RESISTANCE that $\mathrm{y}$ o $\mathrm{u}$ cannot buy in corn elsewhere.

\section{PRICE :}

Per Bushel \$3.25

5 Bushels for $\$ 15.50$

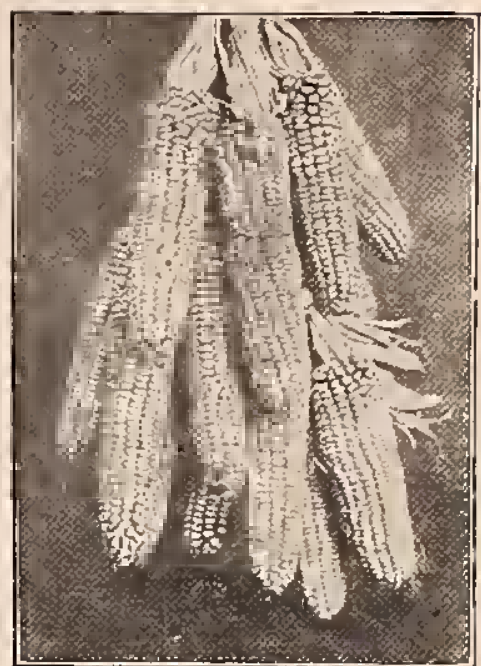

Payne's whlte Dent

Falconer Semi-Dent Yellow Corn

The durshent Yielder in 1930

One of the lighest ylelding and early maturing. More llke fint, other corn stands stlll.

\section{Alta Yellow Dent}

A new pure pedigreed yellow dent corn developed by our State Experment Station. Ripens in 90 days. A medium size yellow corn for
the short season country. Have grown this corn for 3 years and it

Extra Early Black Hills Yellow Dent

This is a smailer corn than the so-called Black Hills corn. It has
been grown by Mr. H. MI. Jenks, southwest of Vale, South Dakotat for over 20 years and was bred up especially for eariness and yield

Squaw and White Flour Corn

This corn made a record of 84 bushels per acre in
Butte County. It made the second highest yield for test conducted by the State College on dry land in Meade County. This is an early selection of Minne
sota No 13 and is the highest yielder of all the yellow
dents. This rariety is rapidly raining in favor becauss of its sure croplying of high yields. Shells well and is

A New Black Hills Cross

To provide a leat enrly maturing, high yielding den w dent. Uneven color. Extra early metturity anà lder.
All our seed corn is carefully selected,
tested, shelled, and graded.

1 bu. $\$ 3.25$

5 bu. $\$ 15.50$ 


\section{GUARANTEE ON NURSERY STOCK}

We will supply you only the best of the respective varieties in trees and shrubs adapted to this short season, dry land section.

We guarantee our stock to be strictly first quality, graded by the highest standards known to the nursery trade. We guarantee it to be in healthy growing condition at the time of delivery. Any stock that does not come up to this guarantee will be replaced without charge upon immediate notification thereof.

\section{REPLACE POLICY}

It sometimes happens that the customer has "bad luck" with his planting and some trees fail to live through. In a case of this kind we agree to replare free all stock properly planted and failing to grow provided written notice is given on or before July 1 , following planting.

\section{Prof. Hansen's Most Famous Plums}

\section{Waneta Plum}

The Giant of Hardy Plums. Up to two inches in diameter. Highly flavored. Richly colored red skin. Considered by many the best and most popular of the Hansen Hybrid Plums and the champion plum of the northwest.

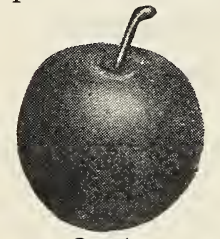

Opata

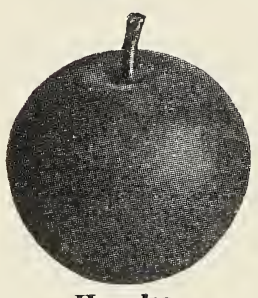

Hanska

\section{Opata Cherry-Plum}

Earliest of all plums and famous everywhere for its rich, wonderfully delicious flavor. The flesh is a light green color with a purplish red skin. Very productive. Hardy throughout the northwest prairies.

\section{Sapa Cherry-Plum}

Early, large, productive and hardy. Its intense black purplish flesh is extra fine eating and wonderful for preserves and jam. Bears the year after planting. A sure annual producer and a favorite everywhere.

\section{Hanska Plum}

The superb plum of apricot flavor and fragrance. Very hardy and productive. Many claim it makes the best jam of any of the Hansen Plums. Highly colored and firm flesh.

\section{Yuteca Plum}

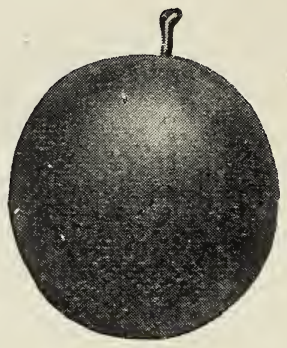

Waneta

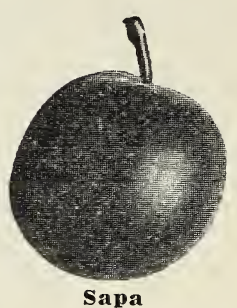

Yuteca is best noted for its heavy annual bearing of very large and early plums. It is one of Prof. N. E. Hansen's very best selected native South Dakota plums. With Yuteca in your orchard you will have plenty of pollen to insure the proper setting of fruit in mixed plum orchards.

\section{Tokata Plum}

The richest flavored of all the Hansen Plums. The fruit is of large size, with rich, orange-red skin and flesh, perfectly free-stone.

\section{Oka Cherry}

Not really a cherry but is a good substitute for a cherry. It is a sand cherry hybrid, a seedling of Champa. Color brighter than Sapa and a black red flesh.

\section{Prepaid Prices on Above Plum Trees}

\begin{tabular}{|c|c|c|c|}
\hline Small size & $\$ 0.45 \mathrm{e}$ & $\$ 3.80$ per 10 & $\$ 9.00$ per 25 \\
\hline Medium size & .60 each & 5.50 per 10 & 13.00 per 25 \\
\hline Large size ... & .80 each & 6.50 per 10 & 15.00 per 25 \\
\hline
\end{tabular}

\section{Free instruction book with all nursery stock orders}




\section{FREE POSTAGE AND EXPRESS ON ALL NURSERY STOCK}

\section{ANOKA-THE WONDER APPLE}

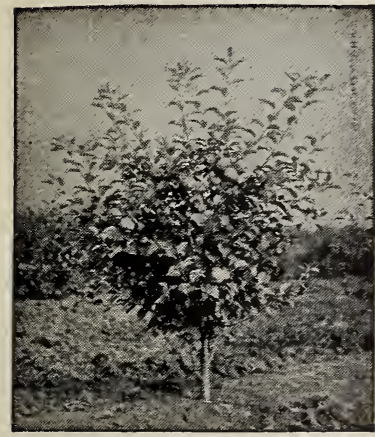

Three Year Anoka Tree

Bearing a Crop of Fruit

The test of years is proving the Anoka to be the most important apple introduction for the Great Plains that has yet come from the laboratory of the Northwest's Burbank, Prof. N. E. Hansen. It bears often the second year from planting, carries large crops every year, is a sturdy, handsome and exceedingly hardy tree. The fruit is of best for the home place under plains condition.

\section{YELLOW TRANSPARENT APPLE}

Earliest summer. This is the best of the extra early apples. Tree moderate grower, very hardy, healthy, comes into bearing very young. Imported from Russia by the United States Department of Agriculture in 1870. Skin thin, tender, smooth, waxy, pale yellow, changing to an attractive yellowish-white. Flesh white, tender, juicy with a pleasant flavor; good to extra good. First hardiness.

WEALTHY APPLES-Well known to all good fruit men of the middle west. A splendid late summer and early fall eating and cooking apple.

DUCHESS APPLES-An old favorite, summer eating apple. Very hardy and productive. A good old stand-by apple.

WHHTNEY CRAB-August to September. A hardy, thrifty, upright grower. The fruit is very large and glossy green, striped with red. The flesh is firm, juicy and pleasant. It is a very heavy yielder and highly prized for cider.

\section{Siberian Flowering Crab}

Or Pyrus Baceata-Windbreak, Ornamental, Fruit Tree, Shade Tree

Introduced from the colder parts of Siberia it is perfectly hardy everywhere. Recommended by the highest authorities as a splendid ornamental of great worth. Known for its strength and hardiness as a great windbreak. Its fruit makes excellent jelly.

Prices on Apples and Crabs

Size

Each Per 10 Per 25

3 to 4 feet

$\$ 0.45 \quad \$ 3.80 \quad \$ 8.00$

4 to 5 feet

$.55 \quad 5.00$

12.00

5 to 6 feet

.75

6.50

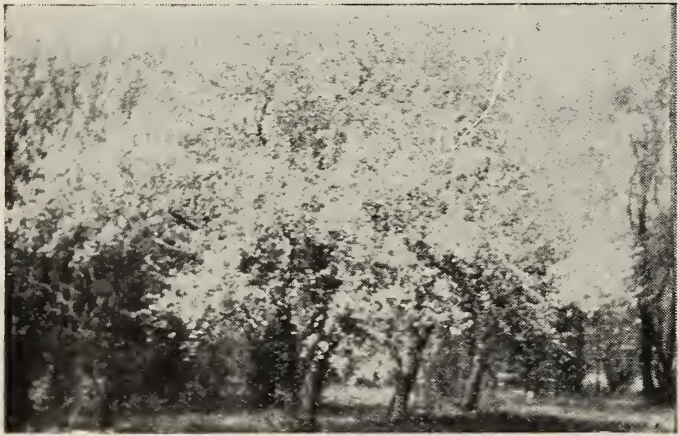

\section{Special Assorted Apple and Plum Orchard}

Mixed orchards of apple or plum trees bear better than if a single variety of apple or plum were planted. An alternate planting of both is better still, as the apples are longer lived and when the plums are ready to be taken out the apples are planted about the proper distance for large trees. The assortments we offer here are made up from a selection of varieties of plums and apples we consider adapted to your section.

\section{Assorted Plum Trees, Large Size, $\$ 6.50$}

12 Assorted Apple Trees, Large Size, \$6.50

\section{Assorted Plum and Apple or Crab Trees, Large Size, $\$ 12.00$}




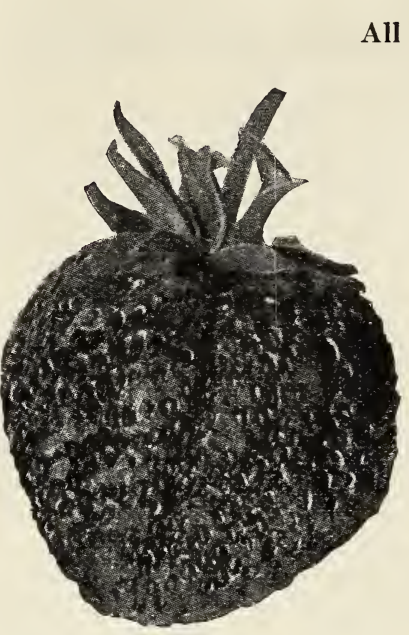

Grand Champion Strawberries
All Nursery Stock at Prepaid Prices

\section{STRAWBERRIES}

\section{The Very Latest and Best}

We are pricing: strawberry plants this year only at prepaid prices. All orders for them will be shipped by themselves as we cannot usually start shipping till near May first and the plants are liable to damage if packed in with other goods.

GRAND CHAMPION-Introducing the very latest in everbearing strawberries. Bigger, more uniform and sweeter than the Mastodon. Originated in the Bitter Root Valley in Montana. The hardiest and best strawberry for this section. It's a prize winner. Order early. Produces wonderful crops in a few months after plants are set, and is sure to revolutionize the strawberry industry with this grand variety. 25 plants, $\$ 1.00$; 50 plants, \$1.75; 100 plants, \$3.00; 300 plants, \$7.50.

Improved strain of Mastodon strawberries at same prices as the Grand Champion.

\section{Beta Grape}

Considered the hardiest of the grapes for the northwest. Not of the best flavor but a great improvement over the native wild, and makes fine jams and jellies and tasty grape juice.

Prices: Each 20c; 5 for 95 ; 10 for $\$ 1.80$; 25 for $\$ 3.25$.

\section{Sunbeam Raspberry}

The most popular and most famous of Prof. N. E. Hansen's red raspberry introductions. The fruits are flaming red in color, of large size, excellent flavor and wonderful keeping quality. It is perfectly hardy everywhere in the northwest, bearing heavy annually, and over a long period of time each season so is thus called everbearing by some. Because of its fine flavor, good keeping, and productiveness it makes a splendid berry for the market as well as for home use. Prices: Each, 15c; 10 plants, $\$ 1.00$; 25 plants, $\$ 1.75 ; 100$ plants, $\$ 4.00$.

\section{Englemanni Ivy}

The hardiest of the climbing vines. Clings by means of sudopads to a sheer wall without the aid of lattice work. Each 50c; 3 for $\$ 1.25$.

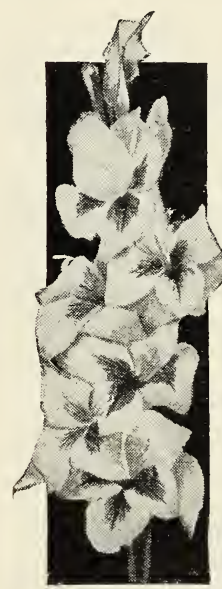

\section{GLADIOLUS}

One of the prettiest and easiest to grow of all the summer flowers. Our assortments are made up of only the choicest standard varieties and will produce a wonderful array of many beautiful flowers.

EXTRA SPECIAL ASSORTMEN'T OF LARGE BULBS Contains 8 to 12 of our best Varieties.

12 Bulbs, postpaid to you, \$0.50; 25 Bullos, postpaid to you, $\$ 1.00$.

SPECIAL LARGE SIZE ASSORTMENT Contains 50 to 75 of Our Best Varieties

Selected for a continuous blooming period that will be sure to please you with many large and brilliant flowers. 100 Choice Large Blooming. Size Bulbs Only \$2.50. Packed Gladioli aud Delivered FREE.

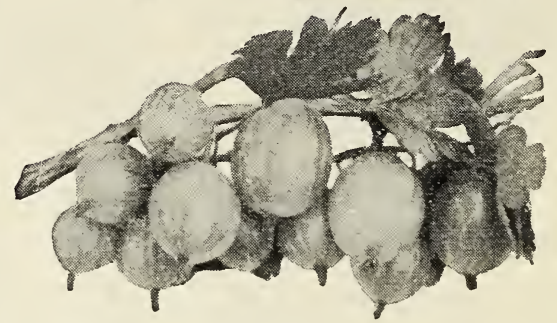

\section{Carrie Gooseberry}

Best of all varieties because of its hardiness, productiveness and fine flavor. Its thornless branches make it a pleasure to pick the fruit.

PRICES: Per Plant 25c; 10 Plants \$2.00; 25 Plants $\$ 4.50$.

\section{Hansen Improved Siberian Black Currant}

The best currant for the Northwest. Hardy everywhere. Very vigorous. Fruits of enormous size, black-red inside and out, and of a particular sweet mellow desirable taste. Excellent for cooking or eating, and makes wonderfully colored dark rich red jam, jelly, or sauce of superb flavor and beauty. Black currant preserves are considered by many of the royalty of Europe to be one of the perfections of preserves in flavor and quality. Heretofore they have been more or less unobtainable here, due to the fact that the Black Currants of Europe are not hardy here. But now Prof. N. E. Hansen has improved and perfected the Siberian Black Currants till they are equal in quality and flavor to the European Black Currants and are hardy everywhere in the Northwest. Prices for Large, strong Stalky Plants: Each, 25c; 5 for $\$ 1.00 ; 10$ for \$1.75; 25 for $\$ 2.50$.

\section{Spirea Van Houttei}

Well known to all and an ornamental of indispensable use. Hardy everywhere. Larke. $\$ 1.00$ each; 3 for $\$ 2.50$; Small, 50c each: 3 for $\$ 1.25$.

Gladiolus and Dahlia bulbs are easily planted and proluce beantiful fowers for this section. 


\section{Lilacs}

The beautiful early flowering shrub of delightful fragrance. Price: Common Purple, White or Persian, 50e each, 5 for $\$ 2.00$ Prepaid.

\section{HARDY HEDGE ROSES}

Nothing is more beautiful in hedges than a rose hedge. And nothing can be hardier than these Hardy Siberian Hedge Roses. They were introduced from Siberia by Dr. N. E. Hansen and have been developed by him for their beauty for years. The result is, we have a wonderful flowering hedge to offer which blooms all summer long from June till it freezes. The flowers are fragrant, large and beautiful beyond words.

With a hedge of these around your lawn you will have a flowering border of beauty to frame your place which will be a continual joy and everlasting pleasure throughout the years to come. Prices for Large, Stocky, Bushy Plants: Each 50e; 5 for $\$ 2.25$; 10 for $\$ 3.75 ; 25$ for $\$ 7.00$ PREPAID.

\section{Peony}

The peony is hardier, easier to grow and as beautiful as the rose.

The superb flower of beauty which gives a radiant joy of glorious color to the garden or lawn. Pink, red and white. 3 Assorted Peonies \$1.25; 6 Assorted Peonies \$2.00; 12 Assorted Peonies \$3.50; Packed and Delivered FREE.

\section{Dahlias}

Beautiful, short season, dry land flower. Dahlias are very easy to grow, require but little care and are very productive of beautiful flowers. They are planted like potatoes and grow easier.

We have all the best good standard choice sorts which produce such large, fine displays of beautiful flowers of many colors and shades. Price: 12 Choice Assorted Tubers \$1.50; 25 Choice Assorted Tubers \$2.50. Packed and Delivered FREF.

\section{Washington Rust Proof Asparagus}

A good vegetable for necessary vitamins in early spring. Every yard should have a row of asparagus.

PRICES PREPAID: Per Root 15e; 10 Roots $\$ 1.00 ; 25$ Roots $\$ 2.25$.

\section{Perfection Currants}

One of the very best for the prairie. Heavy producers, strong and vigorous plants. It produces double the crop and the size of the ordinary varieties.

Prices: Per plant $75 c ; 5$ for $\$ 1.20 ; 10$ for $\$ 2.10 ; 25$ for $\$ 4.75$.

\section{Flowering Almond (Siberian)}

A flowering shrub three to four feet high, of branching habit, blossoms very early in the spring. With a little winter protection these stand the severe winters nicely. 2 to 3 ft., 50c; 5 for $\$ 2.25 ; 10$ for $\$ 4.00$.

\section{AMERICAN ELM}

The best known shade and ornamental, street and lawn tree. Hardy everywhere. Long lived.

\begin{tabular}{|c|c|c|c|c|}
\hline $\begin{array}{l}\text { Size } \\
3-5 \text { ft. } \\
5-7 \text { ft. }\end{array}$ & $\begin{array}{r}\text { Each } \\
.50 \\
1.00\end{array}$ & $\begin{array}{l}10 \\
4.50 \\
8.50\end{array}$ & $\begin{array}{c}25 \\
10.00 \\
20.00\end{array}$ & $\begin{array}{l}100 \\
35.00 \\
75.00\end{array}$ \\
\hline
\end{tabular}

POPLAR

Tall swift growing. Excellent for quick windbreaks.

\begin{tabular}{|c|c|c|c|c|}
\hline $\begin{array}{c}\text { Size } \\
3-4 \text { ft. } \\
4-5 \text { ft. } \\
5-6 \text { ft. }\end{array}$ & $\begin{array}{r}\text { Each } \\
\$ 0.25 \\
.30 \\
.40\end{array}$ & $\begin{array}{l}10 \\
\$ 1.00 \\
1.50 \\
2.00\end{array}$ & $\begin{array}{c}25 \\
\$ 2.00 \\
\mathbf{2 . 5 0} \\
\mathbf{3 . 5 0}\end{array}$ & $\begin{array}{r}100 \\
\$ 5.00 \\
7.50 \\
12.00\end{array}$ \\
\hline
\end{tabular}

CARAGANA Or SIBERIAN PEA TREE

The most popular of all the Russian and Siberian importations. Valuable alike for trimmed hedge, shelter belt or ornamental shrub and one of the very hardiest plants in existence. It is being used extensively and with the best results in farm plantings. Foliage resembles that of the locust, and a dainty yellow pea-like flower covers the plant in late May or June. Bark a handsome green in color. Size, 9 to 15 inches, per $10,65 c$; per $25, \$ 1.25$; per 100, \$3.50. 1 to 2 feet, per 10, 75 ; per 25 , $\$ 1.75$; per 100 , \$5.00.

RUSSIAN OLIVE-(Eleagnus angustifolia.) The hardiest of the Russian importations. Thrives on the poorest soils and withstands drought, heat and cold absolutely. It has small yellow flowers produced abundantly, replaced later by small silvery-white, oliveshaped fruits. When trimmed it makes a beautiful ornamental and when cut back forms a most effective hedge. For hedging, plant 1 foot a part. 12 to 18 inches. each, 10e: 10 for S0e; 50, \$3.00; 100 , \$5.00; 500, \$20.00.
RUSSIAN GOLDEN WILLOW

Very beautiful, rapid grower, does well in low locations. Grows more rapidly than the ordinary willow. The twigs of the Russian Golden are yellow until winter, when they turn a showy red. Half an acre of these trees cut to the ground every few years will keep an ordinary family in fuel. 3 to 4 feet branched, 10 for $81.25 ; 25$ for $\$ 2.50$ Prepaid. AMERICAN GOLDEN WILLOW

Similar to the Russian Golden. Excellent for windbreak purposes. The shiny yellow branches in winter make a valuable addition to any collection of trees. Will make large trees when planted alone. 3 to 4 feet, 10 for \$1.00; 25 for \$2.25 PREPAID.

\section{SIBERIAN BUSH HONEYSUCKLE}

A fine tall hedge plant which is of added value because of its pretty pink and white flowers in early spring followed by masses of bright red and orange fruit, that are of great attraction to the birds.

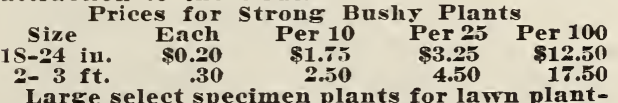

Larce select specimen plants for lawn plantings, 75c each; three for \$2.00; six for $\$ 3.50$.

TARTARIAN BUSH HONEYSUCKLE

The upright or bush form of the Honeysuckle and noted for the great profusion and fragrance of its flowers. Growing from 8 to 12 feet high, these tall growing shrubs are extremely suitable for shrubbery clusters and for individual planting purposes, especially in exposed locations, as they are the last word in hardiness. For hedges they are unsurpassable, being very ornamental in a trained hedge and will stand clipping to any desired shape or form. Mixed colors, 2 to 3 ft., each. 30c; 10, \$2.\$0; 50, \$12.00; 100 , \$22.00 PREPAID.

Plant a few Peonies and Dahlias-a good investment for beauty and pleasure. 


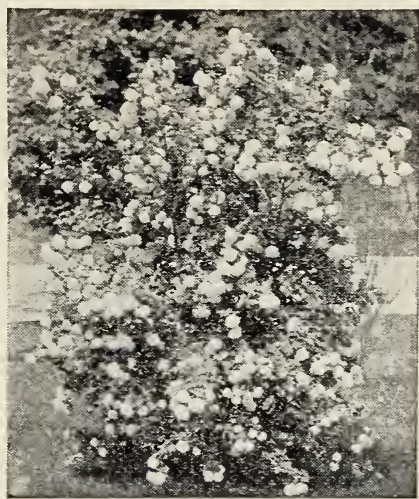

Snowball

\section{SNOWBALL-Viburnum Opulus Sterilis}

An old favorite the country over. Requires a favorable location and plenty of moisture. When conditions are favorable it is unsurpassed among the early blooming shrubs. The last of May or in the first week or two of June it becomes almost completely covered with dense round white flower clusters. 2 to $3 \mathrm{ft}$. size, each, 55c; 5 for $\$ 2.50$ Prepaid.

\section{CLIMBING and RAMBLER ROSES}

\section{Prepaid Prices}

CLIMBING AMERICAN BEAUTY - (My pick.) Rich carmine; fragrant; early bloomer. Plants heavy two-year-old No, 1 stock. Each S5e; 3 for $\$ 2.25$.

DOROTHY PERKIXS - Cle a $r$ shell pink with flowers borne in clusters; full and double. One of the finest of all climbing roses. Each 85c; 3 for $\$ 2.25$.

CRIMSON RAMBLER-The famous crimson-cluster climber, so extremely effective when grown on pillars and trellises. Flowers are produced from ground to tip, in large pyramidal clusters of 30 to 40 . Each 85e; 3 for $\$ 2.25$.

\section{BLACK HILLS SPRUCE}

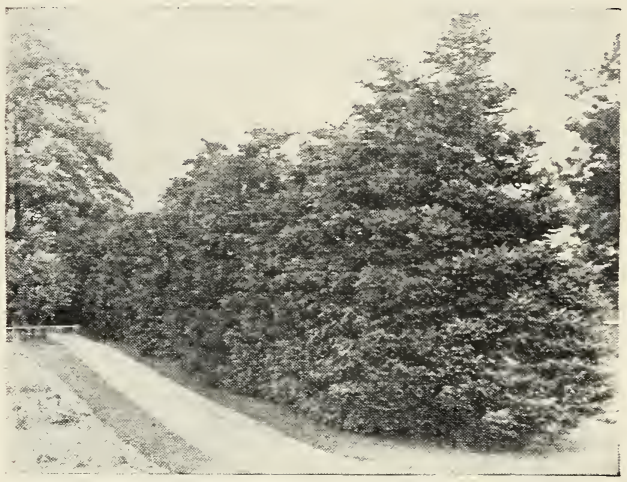

Black Hilis Spruce
The Black Hills

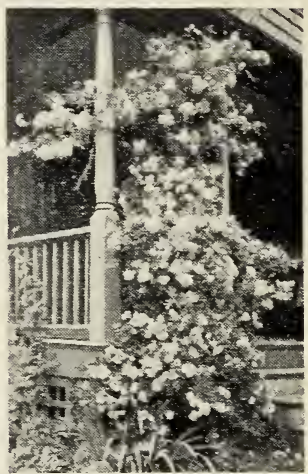

South Dakotative is therefore h a r d y enough for the windswept bare prairie country of the northwest. It grows readily on all soils and because of its close growing branches and heavy close set foliage it is one of the best spruces for ornamental purposes. It will stand trimming well and can be made into a very attractive hedge. Its compact habit of growth lends itself well to windbreak purposes and its dark green color, which it retains throughout the winter months, gives you a promise of the spring to come.

Not balled or burlapped, but twice transplanted and packed carefully: 18-24 in. $\$ 1.55$ each; 10 for $\$ 14.00$. $30-36$ in. $\$ 1.75$ each ; 10 for $\$ 16.00$.

Balled and burlapped in earth, twice transplanted. Not prepaid. 18-24 in. \$2.50 each: 10 for $\$ 22.75 ; 30-36$ in. $\$ 3.10$ each; 10 for $\$ 28.00$; 3 to 4 ft. each $\$ 3 . \$ 5 ; 5$ for $\$ 17.50$

\section{CHINESE ELM}

ULMUS PUMILA (Northern Strain)-The most talked of tree in the world today. Laughs at dry weather, stands more drouth than Caragana or Russian Olive. Fast growing as a Poplar, hardy as an Ash. At home in Dakota, Montana and Wyoming. Trial Order, 10 trees, 4 feet high, \$4.00.

Send this order today-prove the worth of these yourself.

\section{GINNALA MAPLE}

This is a hardy maple from Siberia. A semi-dwarf tree, 14 to 20 feet tall. Hardier than the Soft Maple. The bright colored prettily cut leaves and the immense quantities of seed that they produce make them very attractive trees.

2 to 3 feet, price, each, 40c; 5 for $\$ 1.50 ; 10$ for $\$ 2.50$ PREPAID.

\section{MAY DAY}

The beautiful flowering Lawn Tree. A handsome Siberian shrub resembling our choke-cherry but blooming much earlier. In fact its leaves and blossoms are about the earliest thing to appear in the spring. Flowers in elongated clusters and very fragrant. In blossom the tree is a mass of feathery white plumes.

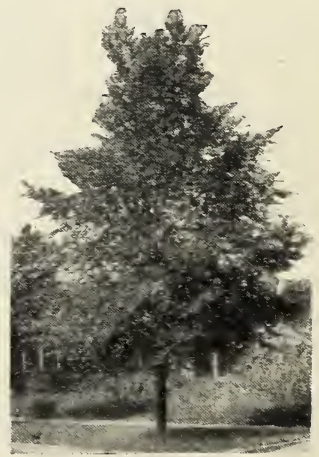

Chinese Elm 3 to 4 feet, transplanted, each, $75 c ; 10$ for $\$ 6.00$.

From Wyoming rancher: "You can count on my business regularly from now on. I have had my lesson with unadapted seed and nursery stock. Sam Bober's Seed and Fruit Trees are the best and the cheapest." 


\section{LAWN GRASS SEED}

Make a home of the house by planting some trees and shrubs and our tested Lawn Grass Seed. Some of the finest homes, schools and government buildings have been beautified by using Sam Bober's Lawn Grass, which has been tested thoroughly under the severe conditions of our climate. It is "good lawn insurance," to sow our lawn seed. There is no purer or better mixture on the market anywhere. Prepaid prices: 60c per lb.; 5 lbs. for $\$ 2.80 ; 10$ lbs. for $\$ 5.00$.
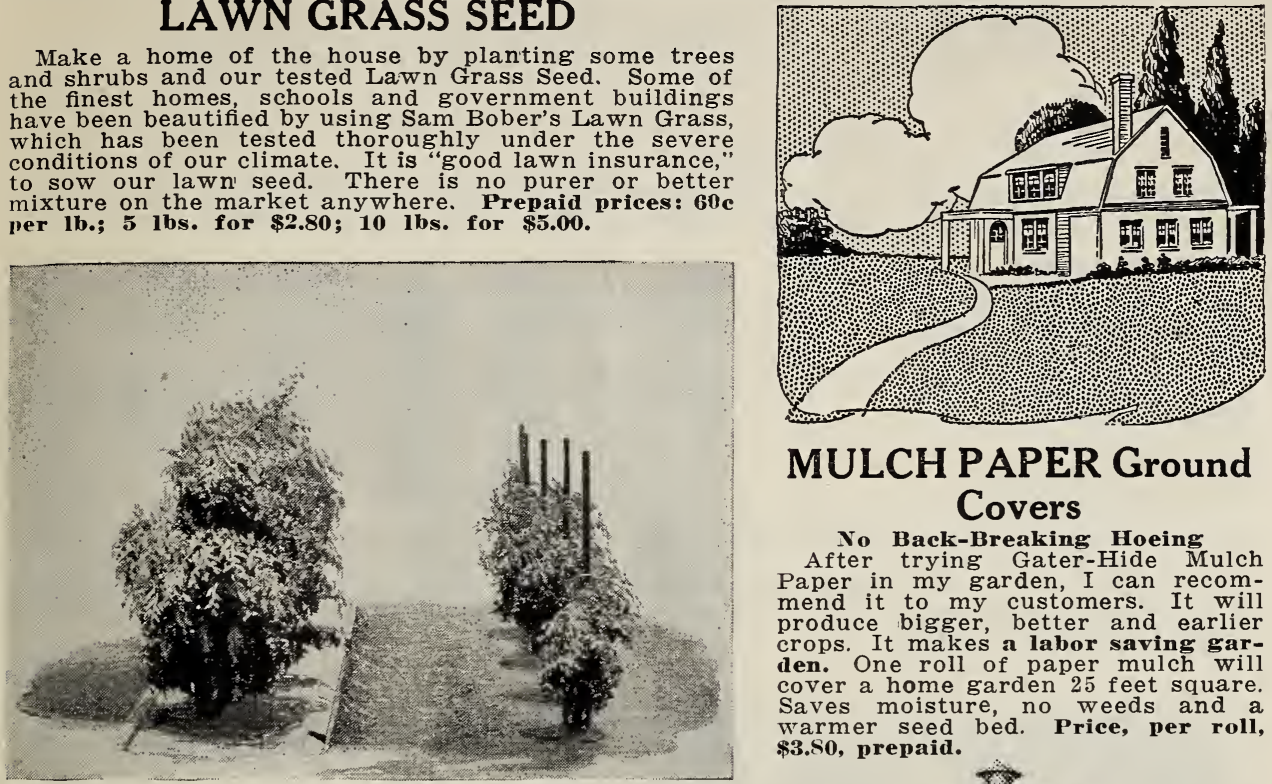

MULCH PAPER Ground

\section{Covers}

No Back-Breaking Hoeing

After trying Gater-Hide Mulch Paper in my garden, I can recommend it to my customers. It will produce bigger, better and earlier crops. It makes a labor saving garden. One roll of paper mulch will cover a home garden 25 feet square. Saves moisture, no weeds and a warmer seed bed. Price, per roll, $\$ 3.80$, prepaid.

\section{HUSKY GIANT}

\section{Portable Grain Storage Bin}

Solves the Farm Storage Problem

It is Rain Proof. Contents securely protected from the weather.

It is Rat Proof. No vermin of any kind can get in when the door is shut.

It is Rot Proof. Large central ventilating tube dries and aerates the grain, preventing heating, mildew or mold.

The Horizontal Corrugations add greatly to the stiffness and strength of the Husky Giant Bins. Generous surplus of material used throughout. Husky bins weigh considerably more than other bins sold at similar price. 500 bu., 840 lbs.; 1,000 bu., 1,200 lbs.

Some of my customers use these bins in the spring for brooder houses for chicks and baby turkeys and for grain storage in the fall.

Prices: 500-bu. bin \$80; 1,000-bu. bin \$120. Delivered to your R. R. station for orders received before July ist.

\section{NEW \\ GARDEN BUGS}

PROTECT your flowers and vegetables this kle with a new kind of non-poisonous powder called PLANTGARD. Not only are bugs worms and insects killed, but this almost magical powder also fertilizes the ground. No wonder flowers grow larger and brighter colored! Vegetables mature quicker and are more tasty. Yet it costs only a few cents to protect an entire garden bed. Ask for Plantgard today.
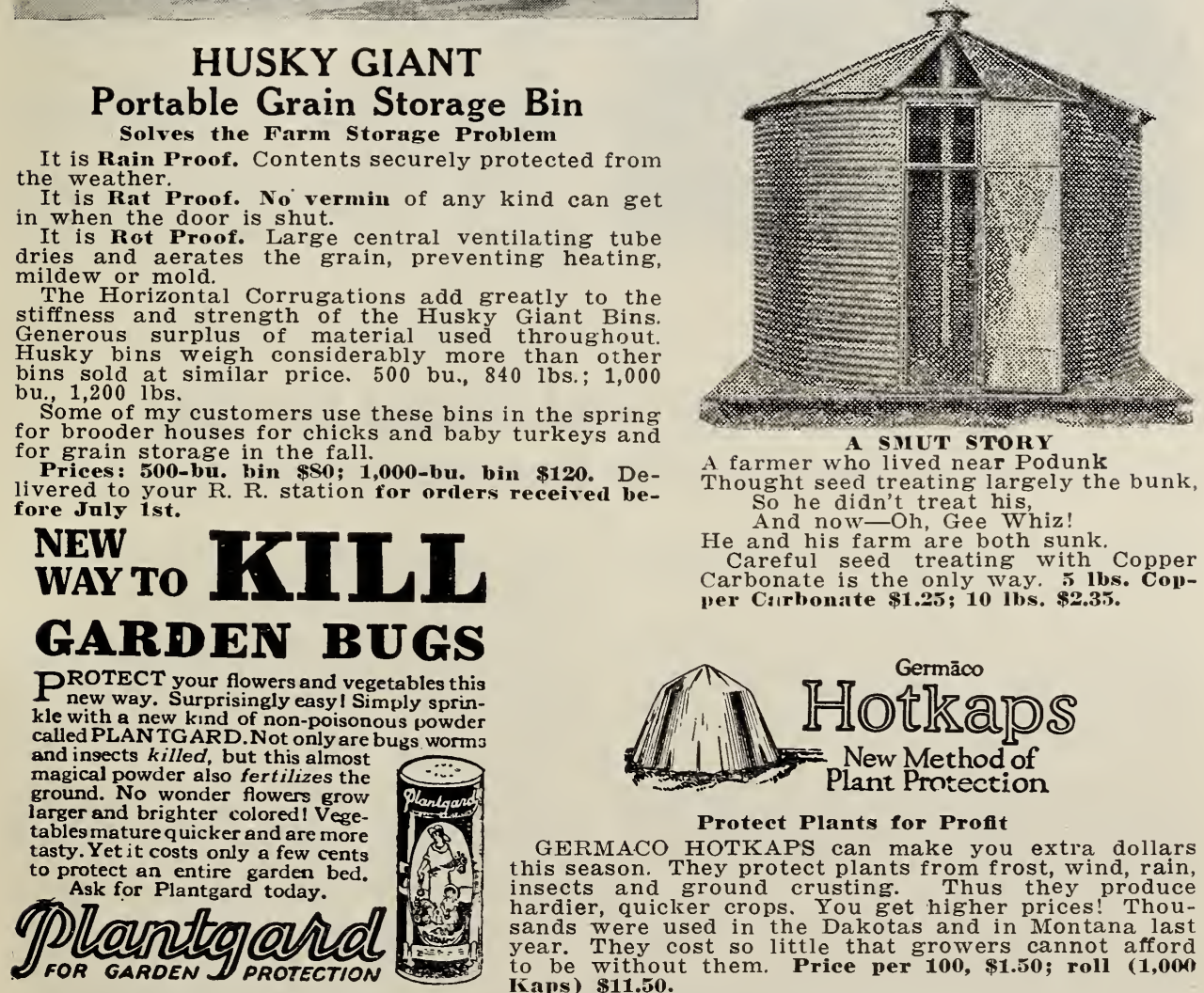

A SUUT STORY

A farmer who lived near Podunk

Thought seed treating largely the bunk So he didn't treat his,

And now-Oh, Gee Whiz!

He and his farm are both sunk.

Careful seed treating with Copper Carbonate is the only way. 5 lbs. Copper Carbonate \$1.25; 10 lbs. \$2.35.

10 oz. carton with sifter top 30c postpaid. 5 lb. container with specially constructed puffer in each packnge, \$1.10 prepaid,

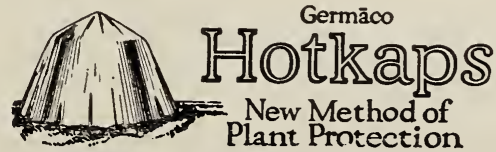

Protect Plants for Profit

GERMACO HOTKAPS can make you extra dollars this season. They protect plants from frost, wind, rain, insects and ground crusting. Thus they produce hardier, quicker crops. You get higher prices! Thousands were used in the Dakotas and in Montana last year. They cost so little that growers cannot afford to be without them. Price per 100, \$1.50; roll (1,000 Kaps) \$11.50.

Every garden in western South and North Dakota, Montana and Wyoming will benefit by the use of these Kaps. I sent out thousands of these Kaps last year and every user is asking for them again. Write for free pamphlet or order today! 


\section{BABY CHICKS Blood Tested, BABY CHICKS State Accredited}

Every flock culled. Every breeder blood tested and banded by a licensed culler. All Breeders Inspected by a State Inspector.

Here is your opportunity to get acclimated Black Hills pure bred baby chicks of the best laying strains. All prices are Prepaid to your Station or Post Office.

\begin{tabular}{|c|c|c|c|c|c|}
\hline Breed of Chicks & 25 & 50 & 100 & 300 & 500 \\
\hline C. White Leghorns. & $\$ 3.50$ & $\$ 6.50$ & $\$ 12.00$ & $\$ 35.00$ & $\$ 58.00$ \\
\hline d Plymouth Rocks. & 4.25 & 8.00 & 15.00 & 44.00 & 72.00 \\
\hline Plymouth Rocks... & 4.25 & 8.00 & 15.00 & & \\
\hline nd Reds. & 4.25 & 8.00 & 15.00 & 44.00 & 72.00 \\
\hline 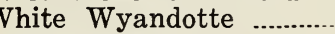 & 4.50 & 8.50 & 16.00 & 47.00 & 77.50 \\
\hline & 4.50 & 8.50 & 16.00 & 47.00 & 77.50 \\
\hline c & 45 & 8.50 & 16.00 & $\cdots$ & ....... \\
\hline
\end{tabular}

Jersey Black Giants

Each 18 cents

Assorted mixed, left after filling orders, $\$ 12$ per 100 chicks.

One hundred per cent arrival guaranteed. We pay shipping cost. Acclimated Chicks of the best breeding obtainable. The most value in breeding stock for your money. SEND YOUR ORDERS EARLY.

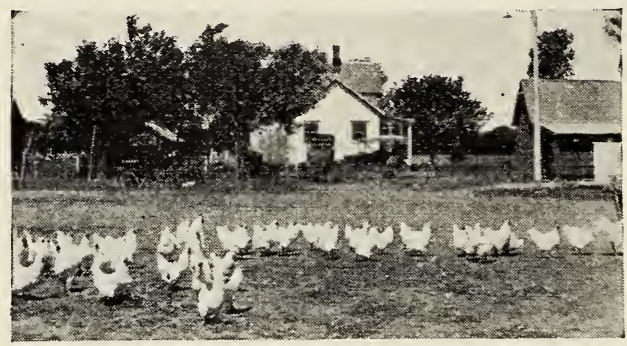

A 25-pound bag of PURINA CHICK STARTER Free with each order for 300 chicks; 50-pound bag of PURINA CHICK STARTER Free with each order for 500 chicks. We prepay shipping charges of PURINA.

We will supply you by mail prepaid any time Fresh PURINA STARTENA for CHICKS and BABY TURKEYS at little above cash price.

A PURINA POULTRY BOOK with a lot of valuable information will be sent FREE with each order for Starter or Growing Mash.

\section{Dry Land Improved Farms for Sale}

My seed business takes most of my time and I cannot spare time to look after all my farm land. I offer the following farms for sale and will give reasonable terms to responsible parties.

160 acres near Sulphur, S. D., $21 / 2$ miles from Highway 212. All seeded to Cossack alfalfa. Fenced. Price $\$ 11.50$ per acre.

1,140 acres on graveled Highway 212, 22 miles east of Newell. 60 acres planted to Cossack alfalfa, 200 acres ready for spring planting, balance farming and pasture land. Partly fenced. Price $\$ 5.25$ per acre. If you have a little money and an outfit, this place will make you good money.

800 acres 17 miles northwest of Newell. 400 acres in registered Grimm alfalfa; 160 acres in Dwarf Sweet Clover, balance farming land. Fenced and cross fenced. Range for stock. A few small buildings. Price, $\$ 12.50$ per acre. The best bargain in the country.
320 acres 10 miles north of Nisland on mail route. 200 acres in Registered Cossack alfalfa. Balance farm land. Well fenced and good small house. Price $\$ 14.00$ per acre.

160 acres 3 miles west of Vale on graveled Highway 79.40 acres in registered Grimm alfalfa, balance farming land. Fenced and cross fenced. 27 acres on this farm are irrigated, good sandy loam. Good small buildings. A dandy place for a farm home. Price $\$ 24.00$ per acre.

480 acres 16 miles from Newell. Sandy loam and some clay soil; 300 acres in Registered Cossack alfalfa. Balance farming land. All fenced in woven wire. Small buildings. One of the best producing dry land farms near Newell. Price $\$ 16.50$ per acre.

40 acres, all irrigated, nice level land, clay soil suitable for sugar beets or general farming. Big six-room house and small buildings. For quick sale will sell for $\$ 25$ per acre. $\$ 500$ down, balance plenty of time.

If you are in position to handle any of the above farms write me at once and I will be glad to give you details and terms. These farms will be rented on March 1 st if not sold by that time.

\section{Address Sam H. Bober, Owner, Newell, South Dakota}




\section{SAM H. BOBER}

Seeds That Will Grow and Produce

NEWELL, SOUTH DAKOTA

\section{ORDER BLANK}

Date.

For the enclosed $\$$. following order.
Name

Street

Address

Post

Office.

Express

Office.

Your Money's Worth or Your Money Back-It is mutually agreed and understood that any seeds or other goods ordered of us may be returned at any time within ten days after receipt, if not satisfactory, and money for them will be refunded, but we do not and cannot in any way warrant the stand or the crop as they depend on so many conditions beyond our control.

Box
Number

Rural

Route

\begin{tabular}{l|c|c|c|c|}
\hline \hline QUANTITY NAME OF VARIETY & \multicolumn{2}{|c|}{ AMOUNT } \\
\hline & & & & \\
\hline
\end{tabular}




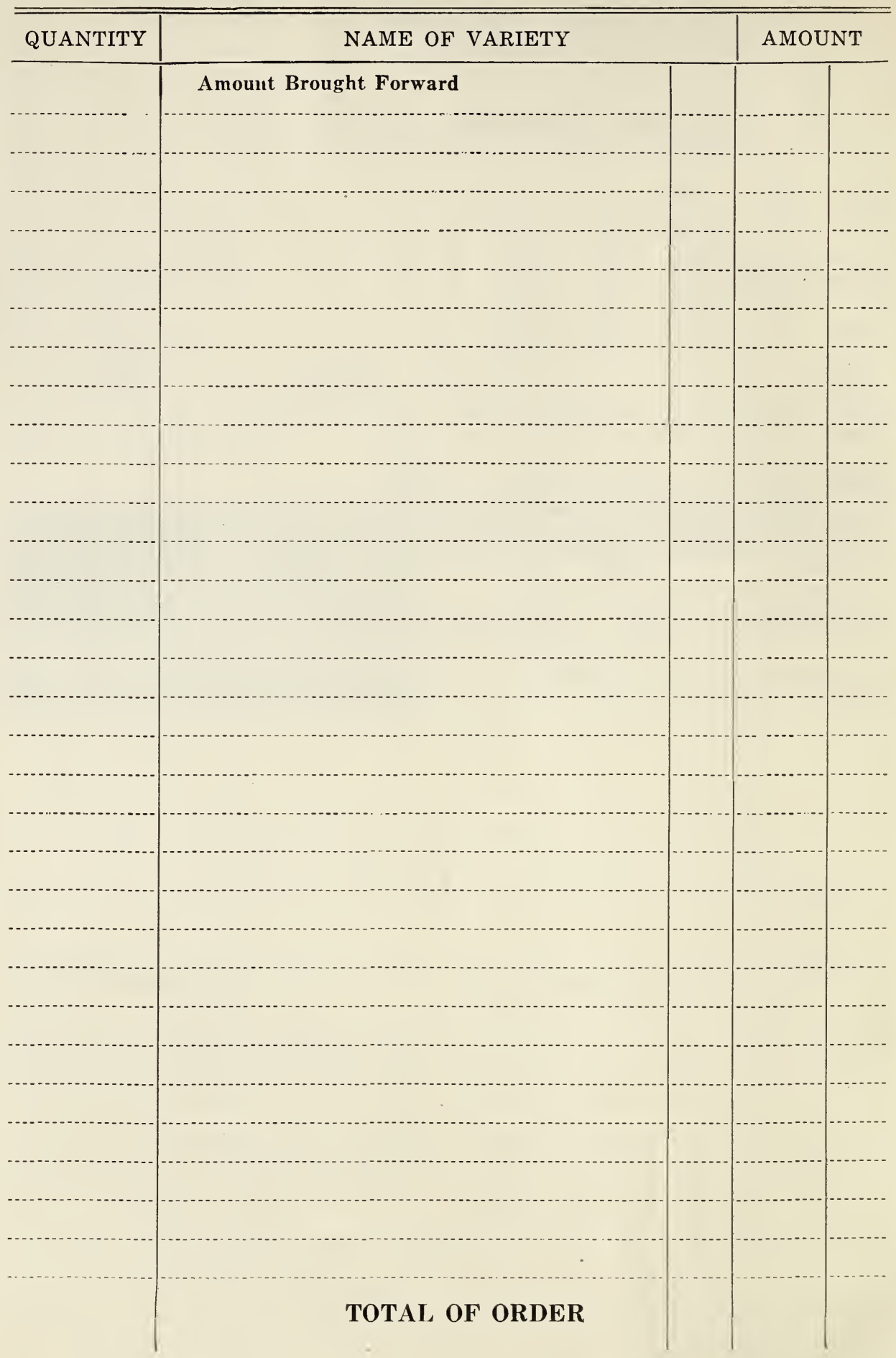




\section{THE CORNER STORE AT NEWELL}

Can save you money on Groceries, Meats and Stock Salt. Send us a list of your needs, we can supply you by Parcel Post at little above our Cash Prices.

\section{Here are a few items postpaid}

No. 1 grade we can send you prepaid to your post office:

4 lbs. best grade Raisins.

4 lbs. Dried Prunes. $\$ 0.40$

1 gallon Sliced or Halves Peaches .72

1 gallon Pitted Cherries................. 1.43

1 gallon Loganberries …................. $\quad .89$

1 gallon Bartlett Pears...................... .83

1 gallon Apricots ............................ .83

1 gallon Crushed Pineapple............. 1.23

1 gallon Royal Anne Cherries........ .94

5 lb. can Honey.............................. .87

$10 \mathrm{lb}$. can Honey.
60 lb. can Dr. Clarke's Famous

White Sweet Clover Honey........ 6.30

We would like to have you try the Famous Vacuum Packed J M Coffee. We can supply it prepaid to your post office as follows:

3 lb. can for.

$10 \mathrm{lb}$. pail for

And a very moderate price Steel Cut Coffee:

5 lbs. Value Coffee.

$\$ 1.15$ 2.20

$10 \mathrm{lbs}$. Value Coffee

Special prices for case goods or large orders.

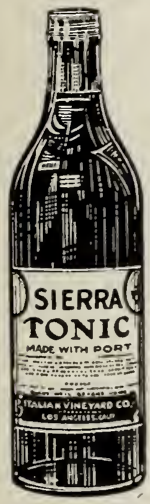

\section{Sierra HEALTH Tonic}

Made from properly matured and aged wines, the average age of the wines being eight years old or more. Various beneficial uses:

Strength and vitality for the ailing.

Rich red blood for the convalescent.

Restful sleep for the aged.

Quiet nerves for the business man.

Patience and renewed vitality for the tired housewife.

A boon to all womankind in the easing of female disorders. Physicians know its value, they admire the honesty of the firm which makes no secret of the medicinal formula which is: Beef extract $1.4 \%$, sodium glycerophosphate 10 grains per fluid ounce, alcohol 22\%. No laxative, except the natural effect of wine. N'o bitters-no "dope"-a legal, useful and effective medicinal preparation. Price: Prepaid 1-16 oz. bottle, $\$ 1.85$.

\section{Pure Concentrated Grape Juice}

From the famous Italian Vineyards Company of California. The OLDEST HEALTH DRINK in a NEW form. One quart can for $\$ 1.80$, Prepaid. Add three parts water. This juice must be used in the home and not sold or transported.

\section{Gold Digger OVERALLS}

Big, roomy and comfortable for work. Husky and hard to wear out. Full 8 oz. Blue Denim that has been carefully preshrunk before you get it and will hold its color with any you've ever seen and better than most. Just the best and strongest reinforced pair of overalls you ever had. One pair, \$1.65; two pair, \$3.20, prepaid.

Send your orders to the Corner Store, Newell, S. D., or you may include them in your order for seeds and nursery stock. 


\section{ALL PLANT LIFE MUST HAVE FOOD}

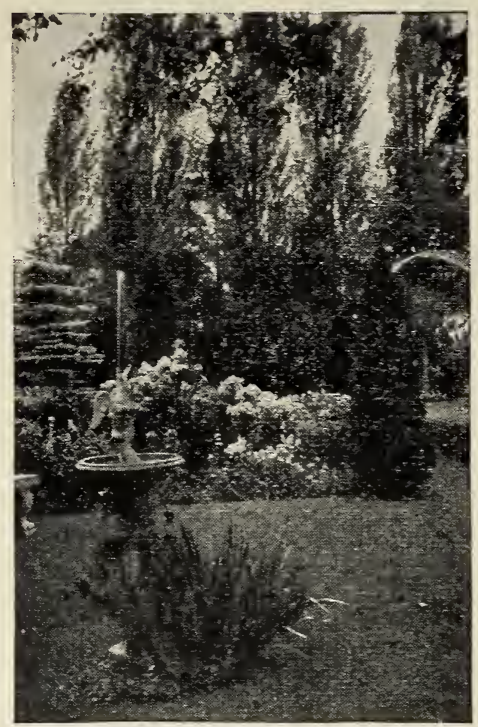

Like human beings, plants require a balanced diet for normal, healthy growth. Vigoro, the complete, scientifically $\mathrm{p}$ r e p a r e d plant food, contains all the nourishment necessary to produce thick, velvety-green lawns; large richly colored flowers; early delicious vegetables and healthy full foliaged trees and shrubs.

Vigoro is clean, odorless and easy to use. It's economical, too! Full directions in every bag.

Prices f.o.b. Newell, South Dakota

$100 \mathrm{lb}$. bag .....\$6.00

50 lb. bag ..... 3.50

$25 \mathrm{lb}$ bag $\ldots \ldots 2.2 .00$

5 lb. pkg. .....60

12 oz. pkg. ..... .10

Special Prices in larger lots.

\section{VIGORO}

A product of Swift \& Company. For lawns, gardens, flowers, shrubs and trees.

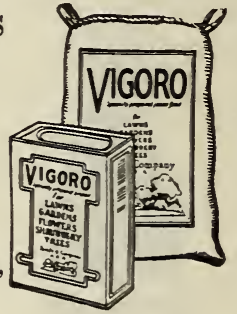

\section{PROFITS FOR SALE}

Your every business purchase, every busi-

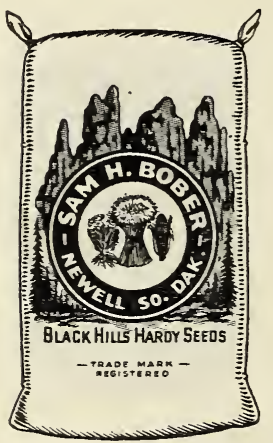
ness action, is for profit. You buy profit. In terms of buying Seed and Nursery Stock, you can likewise buy profit. You can put Sam Bober's adapted Seed and Nursery Stock to work for you, confident of its better yielding ability. It fits your section and your farm and your garden. In 1931 raise a bigger garden and bigger crops with Sam Bober's seeds.

If you wish any sort of seeds or nursery stock not listed here, ask us about it. If we do not have it, we can get it for you in short order.

For information How to Obtain a Government Seed Loan, address Sam H. Bober, Newell, S. D. 